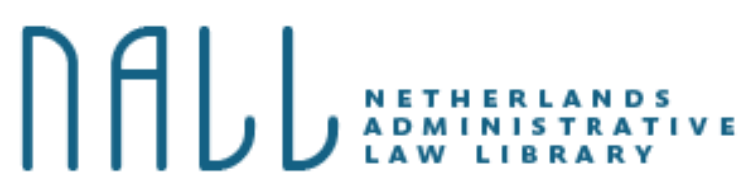

Citeerwijze van dit artikel:

Jacobine van den Brink, 'Europeesrechtelijke eisen aan de verdeling van schaarse

Europese subsidies', NALL 2012, april-juni, DOI: 10.5553/NALL/.000003

DOI: 10.5553/NALLI.000003

\title{
Europeesrechtelijke eisen aan de verdeling van schaarse Europese subsidies
}

\author{
Jacobine van den Brink
}

\section{Inleiding}

Sinds jaar en dag probeert de Europese Unie (hierna: de EU) haar beleidsdoelstellingen mede te realiseren door middel van het verstrekken van Europese subsidies. Deze subsidies worden niet alleen verstrekt door de Europese Commissie en uitvoerende Europese agentschappen, maar ook door nationale autoriteiten. Voorbeelden van Europese subsidies zijn de subsidies uit de Structuurfondsen, ${ }^{\mathbf{1}}$ die onder meer erop zijn gericht de economische verschillen tussen de verschillende EU-regio's terug te brengen, en de onderzoeks- en ontwikkelingssubsidies die worden verstrekt op basis van het zogenoemde Zevende Kaderprogramma. ${ }^{2}$

Voor de meeste Europese subsidieprogramma's is - net als voor de meeste nationale subsidies - een beperkte hoeveelheid geld beschikbaar. ${ }^{3}$ Wanneer de aangevraagde Europese subsidies het beschikbare budget overschrijden, ${ }^{\mathbf{4}}$ is sprake van schaarse Europese subsidies. Zowel Europese als nationale autoriteiten die zijn belast met de verdeling van de schaarse Europese subsidies, worden dan voor de vraag gesteld aan welke Europeesrechtelijke eisen deze verdeling moet voldoen. Welk verdelingsmechanisme moet worden gekozen, in hoeverre zijn de in het aanbestedingsrecht ontwikkelde Europese rechtsbeginselen van gelijkheid en transparantie van toepassing en zo ja, welke eisen vloeien daaruit voort? Deze vragen worden behandeld voor zowel de Europese subsidies die door de Europese Commissie en uitvoerende Europese agentschappen, als de Europese subsidies die door nationale autoriteiten worden verstrekt. In het vervolg van dit artikel zal blijken dat per categorie Europese subsidie verschilt aan welke eisen de verdeling daarvan moet voldoen.

Alvorens de vraag kan worden beantwoord aan welke Europeesrechtelijke eisen de verdeling van schaarse Europese subsidies moet voldoen, wordt in paragraaf 2 eerst besproken wat precies onder het begrip "Europese subsidie" moet worden verstaan. In dat kader wordt ingegaan op het onderscheid tussen 
Europese subsidies die door de Europese Commissie en uitvoerende Europese agentschappen worden verstrekt enerzijds en Europese subsidies die door nationale autoriteiten worden verstrekt anderzijds. In paragraaf 3 wordt vervolgens besproken welk verdelingsmechanisme moet worden gekozen voor de verdeling van Europese subsidies, in hoeverre de beginselen van gelijkheid en transparantie van toepassing zijn en zo ja welke eisen daaruit voortvloeien. In paragraaf 4 volgt een conclusie.

\section{Europese subsidies in soorten en maten}

\subsection{Het Europese subsidiebegrip}

Alvorens wordt ingegaan op de vraag aan welke Europeesrechtelijke eisen de verdeling van Europese subsidies moet voldoen, wordt in deze paragraaf ingegaan op het begrip Europese subsidie. Wat moet onder dit begrip worden verstaan en welke soorten Europese subsidies zijn te onderscheiden? Sinds 2002 is in het Financieel Reglement $\mathbf{5}^{\mathbf{5}}$ - het Europese wetgevingsinstrument voor de implementatie van de EU-begroting - een definitie van het begrip Europese subsidie neergelegd. Het gaat ingevolge artikel $108 \mathrm{om}$ rechtstreekse financiële bijdragen ten laste van de begroting, bij wijze van schenking verleend voor de financiering van a) een actie die moet bijdragen tot de verwezenlijking van een in het kader van het beleid van de EU passende doelstelling; of b) de werking van een orgaan dat een doelstelling van algemeen Europees belang of een in het kader van het beleid van de EU passende doelstelling nastreeft.

Onder deze definitie valt niet de belangrijkste categorie van de gelden die weliswaar ten laste komen van de Europese begroting, maar door tussenkomst van de lidstaten worden verstrekt. Het gaat daarbij om de belangrijke landbouwsubsidies en de subsidies die worden verstrekt uit het structuurfondsen, het Europees Sociaal Fonds (ESF) en het Europees Fonds voor Regionale Ontwikkeling (EFRO). Deze subsidies worden in begrotingstermen "in gedeeld beheer" verstrekt. De subsidietitel van het Financieel Reglement - die allerlei regels bevat voor de verstrekking van Europese subsidies - is op de verstrekking van deze "Europese subsidies" niet van toepassing. ${ }^{6}$ In dit artikel staan echter niet alleen de rechtstreekse financiële bijdragen ten laste van de EU-begroting centraal, maar juist ook de "Europese subsidies" die in gedeeld beheer door nationale autoriteiten worden verstrekt. Het Europees subsidiebegrip dat is neergelegd in artikel 108, tweede lid, van het Financieel Reglement is in het kader van deze bijdrage dan ook te beperkt. Het enige verschil met Europese gelden die in gedeeld beheer door nationale autoriteiten worden verstrekt is dat het niet om rechtstreekse financiële bijdragen ten laste van de EU-begroting gaat. Voor het overige is aan de begripsomschrijving van artikel 108, eerste lid, van het Financieel Reglement voldaan. Om te voorkomen dat steeds een onderscheid moet worden gemaakt tussen Europese subsidies in de zin van artikel 108, eerste lid, van het Financieel Reglement en Europese gelden die in gedeeld beheer door nationale autoriteiten worden verstrekt, is in deze bijdrage voor een bredere definitie van het begrip "Europese subsidie" gekozen. Daarbij wordt zoveel mogelijk aangesloten bij het Europees subsidiebegrip dat is neergelegd in het Financieel Reglement: 
een Europese subsidie is een financiële bijdrage die op directe of indirecte wijze ten laste komt van de EU-begroting, bij wijze van schenking voor de financiering van een actie die moet bijdragen tot de verwezenlijking van een in het kader van het beleid van de EU passende doelstelling.

Het begrip financiële bijdrage geeft aan dat het bij Europese subsidies niet alleen gaat om de betaling van een geldbedrag; het omvat ook bijdragen die op geld kunnen worden gewaardeerd. Hierbij kan bijvoorbeeld worden gedacht aan het verstrekken van een lening tegen een gunstig rentetarief of een garantie. Uit de voormelde definitie komt ten tweede naar voren dat de bijdrage ten laste komt van de EU-begroting; het gaat derhalve niet om subsidies die worden bekostigd vanuit de nationale staatskas. Ten derde kan de financiële bijdrage zowel op directe wijze, dat wil zeggen door de Europese Commissie en uitvoerende Europese agentschappen, dan wel op indirecte wijze, dat wil zeggen door de lidstaten via gedeeld beheer worden verstrekt. Ten vierde gaat het om een schenking; hiermee wordt de Europese subsidie onderscheiden van de overheidsopdracht waarbij het gaat om een betaling van de levering van roerende of onroerende zaken, de uitvoering van werken of het verrichten van diensten. Dergelijke tegenprestaties zijn bij een Europese subsidie nu juist afwezig. Ten slotte gaat het om de financiering van een actie die moet bijdragen tot de verwezenlijking van een in het kader van het beleid van de EU passende doelstelling. Deze EU-doelstellingen zijn te vinden in artikel 3 van het VEU. Het betreft bijvoorbeeld de verwezenlijking van een ruimte van vrijheid, veiligheid en recht, een sociale markteconomie met een groot concurrentievermogen die is gericht op volledige werkgelegenheid en sociale vooruitgang en economische, sociale en territoriale samenhang.

Let wel, het begrip 'Europese subsidie' is als zodanig niet terug te vinden in het Europese recht dat op de verstrekking van Europese subsidies ziet. Daarin wordt onder meer gesproken van 'communautaire steun' - ter onderscheiding van nationale steun,$-{ }^{7}$ premie, ${ }^{\mathbf{8}}$ 'subsidie', 9 'steun'. en 'bijstand'. ${ }^{10}$ Voor zover aan de zojuist geformuleerde definitie is voldaan, is in het kader van deze bijdrage sprake van een Europese subsidie.

Hiervoor kwam al aan de orde dat veel Europese subsidies door nationale autoriteiten worden verstrekt. Subsidies die door organen van de lidstaten worden verstrekt moeten al snel als staatssteun worden aangemerkt. ${ }^{\mathbf{1 1}} \mathrm{De}$ vraag rijst dan ook wat de relatie is tussen het Europees subsidiebegrip en het begrip staatssteun dat is neergelegd in artikel 107 VWEU. Ingevolge deze bepaling zijn, behoudens de afwijkingen waarin de Verdragen voorzien, steunmaatregelen van de Staten of in welke vorm ook met staatsmiddelen bekostigd, die de mededinging door begunstiging van bepaalde ondernemingen of bepaalde producties vervalsen of dreigen te vervalsen onverenigbaar met de interne markt, voor zover deze steun het handelsverkeer tussen de lidstaten ongunstig beïnvloedt. De vraag rijst of Europese subsidies die door nationale autoriteiten worden verstrekt - ondanks dat zij worden gefinancierd met Europees geld - , binnen de reikwijdte van de staatssteunregels vallen. De jurisprudentie van het Hof van Justitie biedt hieromtrent geen duidelijkheid. ${ }^{\mathbf{1 2}}$ In de praktijk wordt er echter van uitgegaan dat de staatssteunregels ook van toepassing kunnen zijn op de verstrekking van Europese subsidies, voor zover aan de overige elementen 
van de staatssteundefinitie is voldaan. Nationale autoriteiten die Europese subsidies verstrekken aan eindontvangers hebben immers zeggenschap over de Europese subsidies gekregen en zijn vrij om deze subsidies - binnen de grenzen van de doelstellingen van de desbetreffende Europese subsidieregeling - te gebruiken om onder meer nationale ondernemingen te ondersteunen. De doelstellingen van een Europese subsidieregeling en ook de daarop gebaseerde door de Commissie goedgekeurde programma's van de lidstaten zijn in veel gevallen dusdanig vaag geformuleerd, dat geen garanties bestaan dat de uiteindelijk door nationale uitvoeringsorganen verstrekte Europese subsidies en de daarbij behorende cofinanciering aan ondernemingen niet als staatssteun zouden kunnen worden gekwalificeerd. Het feit dat de "staatssteun" deels wordt gefinancierd vanuit de Europese begroting is niet relevant; economisch heeft de subsidieverstrekking dezelfde gevolgen voor de concurrentieverhoudingen als een subsidie die uit staatsmiddelen wordt bekostigd. Hoewel over de relatie tussen het begrip Europese subsidie en het begrip staatssteun nog veel meer valt te zeggen, wordt in het kader van deze bijdrage volstaan met de constatering dat de begrippen Europese subsidie staatssteun elkaar dus kunnen overlappen.

In de nu volgende paragrafen wordt dieper ingegaan op de verschillende soorten Europese subsidies die onder de zojuist geformuleerde definitie vallen. In paragraaf 2.2 worden de Europese subsidies die worden verstrekt door de Europese Commissie en uitvoerende Europese agentschappen behandeld. Dit zijn de Europese subsidies die ook vallen onder de subsidiedefinitie neergelegd in artikel 108, eerste lid, van het Financieel Reglement en waarop derhalve de subsidietitel van dat reglement (rechtstreeks) van toepassing is. Paragraaf 2.3 ziet vervolgens op de Europese subsidies die via de lidstaten worden verstrekt. In dat kader moet een onderscheid worden gemaakt tussen Europese subsidies die in gedeeld beheer worden verstrekt (paragraaf 2.3.1) en die derhalve niet onder de subsidiedefinitie van artikel 108, eerste lid, van het Financieel Reglement vallen enerzijds en anderzijds de Europese subsidies die worden verstrekt door publiekrechtelijke en privaatrechtelijke organisaties van de lidstaten. Op deze laatste categorie Europese subsidie is de subsidietitel van het Financieel Reglement wel van toepassing. In paragraaf 2.4 wordt kort ingegaan op de toekomstige herziening van het Financieel Reglement, die ook gevolgen zal hebben voor de inhoud van het Europees subsidiebegrip.

\subsection{Europese subsidies verstrekt door de Europese Commissie en uitvoerende Europese agentschappen}

De eerste categorie Europese subsidies die wordt besproken zijn de subsidies die direct worden verstrekt door de diensten van de Europese Commissie en subsidies waarvoor geldt dat de subsidieverstrekking is gedelegeerd aan uitvoerende Europese agentschappen. ${ }^{\mathbf{1 3}}$ Deze Europese subsidies worden in begrotingstermen op gecentraliseerde wijze verstrekt. ${ }^{\mathbf{1 4}}$ Voorbeelden hiervan zijn het al genoemde "Zevende Kaderprogramma", $\mathbf{1 5}$ maar ook andere programma's zoals "Life+",16 "Marco Polo II"17 en "Progress" ${ }^{18}$ Een voorbeeld van een Europees programma waarvoor geldt dat de uitvoering daarvan is gedelegeerd aan een uitvoerend agentschap is het programma "Europa voor de burger". Dit programma wordt door het Education, Audiovisual \& Culture Executive Agency (EACEA) uitgevoerd. ${ }^{19}$ In voormelde gevallen ontstaat door 
het verstrekken van de Europese subsidie een subsidieverhouding tussen respectievelijk de Europese Commissie en het uitvoerende agentschap enerzijds en de eindontvanger van de Europese subsidie anderzijds. ${ }^{\mathbf{2 o}}$

Op de Europese subsidies die direct door de Europese Commissie en uitvoerende Europese agentschappen worden verstrekt, is de subsidietitel van het Financieel Reglement van toepassing. ${ }^{\mathbf{2 1}}$ Zowel in het Financieel Reglement als de daarop gebaseerde verordening van de Europese Commissie ${ }^{\mathbf{2 2}}$ zijn regels neergelegd die betrekking hebben op de vorm waarin een subsidie kan worden verstrekt $^{\mathbf{2 3}}$, de beginselen waardoor de subsidieverstrekking wordt beheerst ${ }^{\mathbf{2 4}}$, de toekenningsprocedure ${ }^{\mathbf{2 5}}$ en de betaling en controle. ${ }^{\mathbf{2 6}}$ De Europese subsidies die direct door de Commissie ofwel uitvoerende Europese agentschappen worden verstrekt, worden doorgaans verstrekt bij overeenkomst. ${ }^{\mathbf{2}}$

\subsection{Europese subsidies verstrekt door nationale uitvoeringsorganen}

\subsubsection{Subsidieverstrekking in gedeeld beheer}

Wanneer Europese subsidies in gedeeld beheer worden verstrekt, betekent dit dat de Europese subsidies door tussenkomst van de lidstaten worden verstrekt aan eindontvangers van die subsidies. ${ }^{\mathbf{2 8}}$ De lidstaten wijzen de nationale autoriteiten - in dit artikel nationale uitvoeringsorganen genoemd - aan die worden belast met de uitvoering van de desbetreffende Europese subsidieregeling. De methode van gedeeld beheer gold oorspronkelijk alleen voor de Structuurfondsen, het Europees Visserijfonds, het Europees Landbouwgarantiefonds (ELGF) en het Europees Landbouwfonds voor Plattelandsontwikkeling (ELFPO). ${ }^{\mathbf{2 9}}$ Inmiddels wordt het gedeeld beheer op ruimere schaal toegepast, zoals ten aanzien van de Migratiefondsen en het Europees Globaliseringsfonds. ${ }^{30}$

De Europese structuurfondsen Europees Sociaal Fonds (ESF) en het Europees Fonds voor Regionale Ontwikkeling (EFRO) hebben ten doel om de verschillen tussen de ontwikkelingsniveaus van de verschillende regio's en de achterstand van de minst begunstigde regio's te verkleinen. ${ }^{31}$ Vanuit het Europees Visserijfonds worden Europese subsidies verstrekt ten behoeve van de duurzame ontwikkeling van de visserijsector, visserijgebieden en de binnenvisserij. ${ }^{32}$ De Europese landbouwsubsidies die uit het ELGF worden verstrekt zijn gericht op het verschaffen van een inkomen aan landbouwers, ${ }^{33}$ terwijl de subsidies die vanuit het ELFPO worden gefinancierd de plattelandsontwikkeling op het oog hebben. ${ }^{34}$ De relatief nieuwe migratiefondsen - het Europees Vluchtelingenfonds (EVF), ${ }^{35}$ het Europees Terugkeerfonds (ETF), ${ }^{36}$ het Europees Integratiefonds (EIF) ${ }^{37}$ en het Europees Buitengrenzenfonds $(\mathrm{EBF})^{38}$ - zijn gericht op een eerlijke verdeling van met name de financiële lasten die voortvloeien uit de invoering van een geïntegreerd beheer van de buitengrenzen van de Unie en uit het gemeenschappelijk asiel- en immigratiebeleid. Het Europees Globaliseringsfonds ten slotte is opgericht om de EU in staat te stellen subsidies te verstrekken aan werknemers die worden ontslagen als gevolg van door de globalisering veroorzaakte grote structurele veranderingen in de 
wereldhandelspatronen, in gevallen waarin deze collectieve ontslagen een zeer negatieve impact hebben op de regionale of plaatselijke economie. ${ }^{39}$

Gedeeld beheer houdt in dat de Commissie en de lidstaten verschillende administratieve taken hebben die onderling van elkaar afhankelijk zijn en wettelijk zijn vastgesteld, en waar zowel de Commissie als de lidstaten hun respectieve taken ten uitvoer moeten leggen om te komen tot een succesvolle tenuitvoerlegging van het Europese beleid. ${ }^{40}$ De verhouding tussen de Europese Commissie en de lidstaten is neergelegd in specifieke Europese verordeningen en besluiten. Voorop staat dat uit deze regelgeving volgt dat de lidstaten in de eerste plaats verantwoordelijk zijn voor de verstrekking van de Europese subsidies. ${ }^{41}$ De spelregels voor deze verstrekking zijn echter in hoge mate terug te vinden in voormelde Europese verordeningen en besluiten. ${ }^{42}$ De eigen verantwoordelijkheid van de lidstaten is derhalve sterk Europees genormeerd.

Het systeem van subsidieverstrekking in gedeeld beheer komt er kort gezegd op neer dat de lidstaten meerjarenprogramma's opstellen waarin zij aangeven uiteraard binnen de grenzen van de toepasselijke Europese verordeningen en besluiten - welke soort projecten zij voor Europese subsidies in aanmerking willen laten komen en hoe zij de uitvoering van de Europese verordeningen en besluiten op nationaal niveau denken te realiseren. ${ }^{\mathbf{4 3}}$ Deze programma's worden afhankelijk van de desbetreffende Europese subsidieregeling operationeel programma, ${ }^{4 \mathbf{4}}$ plattelandsontwikkelingsprogramma $\mathbf{4 5}^{\mathbf{5}}$ of meerjaarlijks programma ${ }^{46}$ genoemd. De programma's worden bij de Europese Commissie ingediend en dienen door haar te worden goedgekeurd, alvorens het bevoegde nationaal uitvoeringsorgaan kan beginnen met het verstrekken van Europese subsidies. De goedkeuring door de Europese Commissie gaat doorgaans gepaard met de vaststelling van het maximumbedrag aan Europese gelden dat voor het desbetreffende programma beschikbaar is. ${ }^{47} \mathrm{Op}$ basis van deze goedgekeurde programma's verstrekken door de lidstaat aangewezen nationale uitvoeringsorganen Europese subsidies aan de nationale ontvangers, aangevuld met een verplicht te verstrekken nationale subsidie. Deze met nationaal geld bekostigde aanvulling op de Europese subsidie wordt nationale cofinanciering genoemd. Doorgaans gaat het om een verplichte cofinanciering van 50\%. De ratio hiervan is dat de EU geen Europese subsidies wenst te besteden, waarvoor nationale autoriteiten zelf geen nationale subsidie over hebben. De aan de nationale ontvangers gedane betalingen in het kader van een verstrekte Europese subsidie worden door nationale uitvoeringsorganen gedeclareerd bij de Europese Commissie, door middel van zogenoemde betalingsaanvragen op grond waarvan tussentijdse betalingen worden verricht. ${ }^{48}$ Zowel gedurende de periode van subsidieverstrekking als bij de vaststelling van de Europese subsidie verrichten nationale uitvoeringsorganen controles bij de ontvangers van de Europese subsidies. Indien onregelmatigheden worden geconstateerd, dient de Europese subsidie te worden ingetrokken en teruggevorderd. De lidstaten kunnen tot een in de Europese subsidieregeling neergelegde datum een aanvraag tot betaling van het eindsaldo van het desbetreffende programma indienen. $\mathbf{4 9}$ Na controles door de Europese Commissie wordt het programma afgesloten.

Als een Europese subsidie in gedeeld beheer wordt verstrekt, ontstaan derhalve twee subsidierelaties: een subsidierelatie tussen de Europese Commissie en de 
lidstaat, op basis van een door de Commissie goedgekeurd programma, en een subsidierelatie tussen het nationale uitvoeringsorgaan en de eindontvanger van de Europese subsidie..$^{50}$ Deze laatste subsidierelatie wordt, voor zover geen Europese regels voorhanden zijn, beheerst door het nationale recht (procedurele autonomie). $\mathbf{5 1}^{\mathbf{1}}$ Dit nationale recht moet voldoen aan de bekende Europese beginselen van gelijkwaardigheid en doeltreffendheid..$^{\mathbf{2}}$

\subsubsection{Subsidieverstrekking door publiekrechtelijke en privaatrechtelijke organisaties van de lidstaten}

De verstrekking van Europese subsidies door nationale uitvoeringsorganen vindt niet alleen plaats in de context van gedeeld beheer. Op grond van artikel 54, tweede lid, onder c, van het huidige Financieel Reglement is het voor de Europese Commissie ook mogelijk Europese subsidies te laten verstrekken door nationale publiekrechtelijke organen of privaatrechtelijke organen belast met een openbare dienstverleningstaak, die voldoende financiële garanties bieden en de in de uitvoeringsvoorschriften vastgestelde voorwaarden in acht nemen. 53 Ondanks het feit dat voor de uitvoering van dergelijke Europese subsidieregelingen nationale uitvoeringsorganen worden ingeschakeld, gaat het om Europese subsidies die op (indirect) gecentraliseerde wijze worden verstrekt. Omdat de Europese subsidies zelf niet eerst in de begroting van de lidstaat vloeien, is immers sprake van een rechtstreekse financiële bijdrage ten laste van de Europese begroting. Op deze Europese subsidies is de subsidietitel van het Financieel Reglement dus van toepassing. Van de subsidiedefinitie zijn wel uitgezonderd de betalingen aan voormelde nationale organen. Het gaat daarbij echter om de betaling van de operationele kosten van deze organen, niet om de Europese subsidies die zij verstrekken.54

De belangrijkste Europese subsidies die op grond van artikel 54, tweede lid, onder c, van het Financieel Reglement door nationale publiekrechtelijke organen worden verstrekt, zijn de subsidies uit hoofde van de programma's Een Leven Lang Leren en Jeugd in Actie.55
Op grond van het subsidieprogramma Een Leven Lang Leren worden onder meer Erasmus-beurzen verstrekt aan studenten voor studieactiviteiten in het buitenland. Het programma Jeugd in Actie is gericht op jongeren tussen de 15 en 28 jaar en heeft onder meer tot doel het bevorderen van het actieve burgerschap van jongeren in het algemeen en het Europese burgerschap in het bijzonder.

De uitvoering van de Europese subsidieregelingen Een Leven Lang Leren en Jeugd in Actie geschiedt op grond van de Europese subsidieregelgeving deels door het uitvoerend agentschap EACEA ${ }^{\mathbf{5}}$ en deels door nationale agentschappen. Een nationaal agentschap dient door de lidstaat te worden aangewezen of opgericht. Een agentschap moet rechtspersoonlijkheid hebben of deel uitmaken van een instantie die rechtspersoonlijkheid heeft en dient te vallen onder de wetgeving van de betrokken lidstaat. ${ }^{57}$ Volgens de toepasselijke Europese subsidieregelgeving mag een ministerie niet als nationaal agentschap worden aangewezen. ${ }^{\mathbf{5 8}}$ Gelet op deze voorschriften heeft Nederland ervoor gekozen privaatrechtelijke stichtingen als nationaal agentschappen aan te 
wijzen. Het Nederlandse Nationaal Agentschap Een Leven Lang Leren bestaat uit drie stichtingen namelijk de NUFFIC,59 het CINOP60 en het Europees Platform. Als Nederlands Nationaal Agentschap Jeugd in Actie is aangewezen de Nederlandse stichting het Nederlands Jeugdinstituut. ${ }^{61}$

Uit de besluiten van de Commissie waarin de verantwoordelijkheden van respectievelijk de lidstaten, de Commissie en de nationale agentschappen bij de uitvoering van de actieprogramma's Een Leven Lang Leren en Jeugd in Actie zijn neergelegd, volgt dat de nationale agentschappen zijn belast met de verstrekking van Europese subsidies. ${ }^{\mathbf{6 2}}$ Ook hier ontstaan twee subsidierelaties, namelijk tussen de Europese Commissie en de nationale agentschappen en tussen de nationale agentschappen en de eindontvangers van de Europese subsidies. Er komt derhalve geen subsidierelatie tot stand tussen de Europese Commissie en de eindontvanger van de Europese subsidie. De subsidierelatie tussen de Europese Commissie en de nationale agentschappen wordt geregeld door de gidsen voor nationale agentschappen en jaarlijkse financiële overeenkomsten. ${ }^{63}$ De subsidierelatie tussen de nationale agentschappen en de eindontvangers van de Europese subsidie wordt, voor zover er geen Europese regels zijn, beheerst door het nationale recht (procedurele autonomie). ${ }^{64}$ Dit nationale recht moet eveneens voldoen aan de Europese beginselen van gelijkwaardigheid en doeltreffendheid. De verstrekking van Europese subsidies door nationale agentschappen is, in vergelijking met Europese subsidies die gedeeld beheer worden verstrekt, echter wel meer geëuropeaniseerd. Zo wordt de mogelijkheid om aanvragen in te dienen om voor een Europese subsidie in aanmerking te komen gepubliceerd in het Europese publicatieblad, ook voor de aanvragen die bij nationale agentschappen moeten worden ingediend. Voorts is in de jaarlijks door de Europese Commissie uit te geven programmagidsen precies neergelegd voor welke projecten een Europese subsidie kan worden verkregen. ${ }^{65}$ Anders dan gebruikelijk is bij Europese subsidies verstrekt in gedeeld beheer, stellen de lidstaten dan ook geen programma's op die door de Europese Commissie worden goedgekeurd. Uit de Europese subsidieregelgeving blijkt echter wel dat de nationale agentschappen op eigen verantwoordelijkheid subsidieaanvragen selecteren en een subsidierelatie aangaan met de eindontvangers van de Europese subsidie. Geschillen die zich in het kader van deze relatie voordoen worden uiteindelijk beslecht door een nationale rechter. ${ }^{\mathbf{6 6}}$ Beslissingen van nationale agentschappen worden dan ook niet aan de Europese Commissie toegerekend. ${ }^{67}$

\subsection{Toekomstige ontwikkelingen}

Inmiddels ligt er een voorstel van de Europese Commissie tot herziening van het Financieel Reglement. ${ }^{\mathbf{6 8}}$ De subsidiedefinitie blijft in het voorstel ongewijzigd. Nieuw is dat de methoden van de uitvoering van de Europese begroting sterk worden vereenvoudigd. Zoals de Commissie zelf in een eerdere versie van het voorstel voor een nieuw Financieel Reglement aangeeft, zijn de bepalingen van het huidige Financieel Reglement inzake indirect, gedecentraliseerd, gedeeld, en gezamenlijk beheer zo complex, dat niemand nog weet wat het oorspronkelijke doel ervan is. ${ }^{69}$ Vandaar dat in het voorstel slechts een onderscheid wordt gemaakt tussen Europese subsidies die worden verstrekt volgens de methode van direct beheer enerzijds en subsidies die worden verstrekt volgens de 
methode van indirect beheer anderzijds. ${ }^{70}$ De Europese subsidies verstrekt via de diensten van de Europese Commissie en door tussenkomst van uitvoerende Europese agentschappen worden volgens de methode van direct beheer verstrekt. ${ }^{\mathbf{7}}$ Onder de noemer van indirect beheer vallen vanaf de inwerkingtreding van het nieuwe Financieel Reglement ten eerste de Europese subsidies die thans in gedeeld beheer worden verstrekt. In tegenstelling tot in het huidige Financieel Reglement worden ten tweede de Europese subsidies verstrekt door de huidige nationale agentschappen Een Leven Lang Leren en Jeugd in Actie eveneens volgens de methode van indirect beheer verstrekt. ${ }^{\mathbf{2}}$ Dit heeft tot gevolg dat de subsidietitel van het Financieel Reglement niet meer op de subsidieverstrekking door nationale agentschappen van toepassing zal zijn. ${ }^{73}$

In het vervolg van dit artikel wordt echter uitgegaan van de huidige situatie en een onderscheid gemaakt tussen Europese subsidies die worden verstrekt door de Europese Commissie, uitvoerende Europese agentschappen en nationale agentschappen enerzijds en Europese subsidies die in gedeeld beheer worden verstrekt anderzijds. Alleen op de eerste categorie Europese subsidies is de subsidietitel van het Financieel Reglement momenteel van toepassing. Zoals uit de volgende paragraaf zal blijken, heeft dit consequenties voor de Europese eisen die aan de verdeling van de Europese subsidies worden gesteld.

\section{Europeesrechtelijke eisen aan de verdeling van schaarse Europese subsidies}

\subsection{Algemeen}

In de inleiding is reeds kort aan de orde gekomen dat voor de meeste Europese subsidies geldt dat een beperkt budget beschikbaar is. Dit beperkte budget komt wat betreft de Europese subsidies die door de Europese Commissie en de uitvoerende Europese agentschappen worden verstrekt tot uitdrukking in de desbetreffende Europese subsidieregeling. ${ }^{\mathbf{7 4}}$ Wat betreft Jeugd in Actie en Een Leven Lang Leren is in de jaarlijks te sluiten overeenkomst tussen de Europese Commissie en de nationale agentschappen bepaald welk bedrag aan Europese subsidies voor een lidstaat beschikbaar is. ${ }^{\mathbf{7 5}}$ Voor de Europese subsidies die in gedeeld beheer worden verstrekt, geldt dat de Commissie in afzonderlijke besluiten waarbij de in de vorige paragraaf besproken programma's die de lidstaten hebben opgesteld worden goedgekeurd, is vermeld hoeveel Europees geld voor dat programma beschikbaar is. ${ }^{\mathbf{7 6}}$ Uiteindelijk zijn de beschikbare Europese subsidies gebaseerd op het meerjarig financieel kader dat wordt vastgesteld uit hoofde van artikel 312 VWEU. In dit kader wordt neergelegd hoeveel middelen de EU gedurende een bepaalde programmaperiode ter beschikking heeft om onder meer Europese subsidies te bekostigen. Het meerjarig financieel kader voor de programmaperiode 2007-2013 is neergelegd in het interinstitutioneel akkoord tussen het Europees Parlement, de Raad en de Commissie van 17 mei 2006.77

In de Europese subsidieregelgeving is geen bepaling te vinden die voorschrijft dat subsidieaanvragen worden afgewezen, indien er onvoldoende budget beschikbaar is. Uiteraard impliceert het beperkte budget wel dat niet iedere aanvraag om Europese subsidie kan worden toegewezen; het beschikbare bedrag 
dient over de verschillende subsidieaanvragen te worden verdeeld. In paragraaf 3.2 wordt eerst onderzocht in hoeverre het Europese recht voorschrijft door middel van welk systeem de verdeling van schaarse Europese subsidies moet plaatsvinden. Vervolgens bespreek ik in paragraaf 3.3 de Europese eisen die worden gesteld aan de verdeling van Europese subsidies die op (indirect) gecentraliseerde wijze worden verstrekt. Het gaat daarbij om de Europese subsidies die door de Europese Commissie, de uitvoerende Europese agentschappen en de nationale agentschappen worden verstrekt. Ter illustratie wordt ingegaan op de toekenningsprocedure in het kader van het Europees subsidieprogramma's Een Leven Lang Leren en Jeugd. Aan de toekenningsprocedure die is voorgeschreven voor Europese subsidies die op (indirect) gecentraliseerde wijze worden verstrekt, liggen - zo zal blijken - de beginselen van gelijkheid en transparantie ten grondslag. Paragraaf 3.4 ziet op de vraag in hoeverre deze beginselen ook van toepassing zijn op de verdeling van Europese subsidies die in gedeeld beheer worden verstrekt. Ten slotte wordt in paragraaf 3.5 besproken in hoeverre de Europese subsidieregelgeving eisen stelt aan de rechtsbescherming tegen schendingen van de beginselen van gelijkheid en transparantie bij de verdeling van schaarse Europese subsidies.

\subsection{Europeesrechtelijke eisen aan de subsidieverdelingssystematiek}

In deze paragraaf wordt bezien welke systematiek ingevolge de Europese subsidieregelgeving moet worden toegepast bij de verdeling van Europese subsidies. Voor de verdeling van schaarse Europese subsidies zijn verschillende systemen denkbaar, zoals een "wie het eerst komt, het eerst maalt"-systeem, een tenderprocedure, een loting of een evenredige verdeling van de Europese subsidies over alle aanvragen. ${ }^{\mathbf{7}}$

Ten aanzien van de Europese subsidies die door de Europese Commissie, Europese uitvoerende agentschappen en nationale agentschappen worden verstrekt, is expliciet voorgeschreven dat zij moeten worden verdeeld door middel van een tenderprocedure. ${ }^{79}$ Een tenderprocedure betekent ook Europeesrechtelijk dat alleen die aanvragen worden gehonoreerd die na onderlinge vergelijking op bepaalde toekenningscriteria als de besten uit de bus komen. ${ }^{\mathbf{8 0}}$ In de Nederlandse literatuur wordt de tenderprocedure ook wel "beauty contest" genoemd. ${ }^{\mathbf{8 1}}$

Voor de Europese subsidies die in gedeeld beheer worden verstrekt is in veel gevallen voorgeschreven dat het nationale uitvoeringsorgaan de procedures instelt voor de selectie van projecten die voor subsidies in aanmerking komen. ${ }^{\mathbf{8 2}}$ Hieronder valt ook de wijze van verdeling van de schaarse Europese subsidies. Een voorgeschreven specifiek verdeelsysteem valt hieruit echter niet af te leiden. In de Europese subsidieregelgeving inzake de migratiefondsen is voorts bepaald dat een beoordeling op kwaliteit dient plaats te vinden. ${ }^{\mathbf{8 3}}$ Hoewel alleen in tenderprocedures de kwaliteit van de aanvragen met elkaar worden vergeleken, is een beoordeling op kwaliteit ook mogelijk in andere verdeelsystemen. In een "wie het eerst kom, het eerst maalt"-systeem kunnen bijvoorbeeld kwalitatieve drempelcriteria worden gehanteerd. In de Europese subsidieregelgeving inzake de Migratiefondsen, de Structuurfondsen, het Europees Visserijfonds en het 
ELFPO is, anders dan ten aanzien van de Europese subsidies die op gecentraliseerde wijze worden verstrekt, thans dus geen expliciete verplichting neergelegd om een tenderprocedure te hanteren.

In het kader van de verdeling van Europese subsidies uit het Europees Oriëntatie en Garantiefonds voor de Landbouw (afdeling Oriëntatie) - de voorloper van het ELFPO - heeft het Hof van Justitie in het arrest JK Otsa Talu overwogen dat de lidstaten zich ervoor moeten inspannen dat zij aan iedere in aanmerking komende aanvrager een Europese subsidie kunnen verlenen. ${ }^{\mathbf{8 4}}$ Uit hetzelfde arrest blijkt dat dit lastig kan zijn, zeker als de lidstaat onvoldoende middelen heeft om de vereiste nationale cofinanciering te financieren. In dat geval is het volgens het Hof geoorloofd dat het nationale uitvoeringsorgaan de kring van nationale ontvangers beperkt tot alleen die landbouwers die het vorige begrotingsjaar ook een subsidie hebben ontvangen. ${ }^{\mathbf{8 5}}$ Ook uit de Europese jurisprudentie kan dus geen voorkeur voor een van de voormelde verdeelsystemen worden afgeleid.

Het voorgaande duidt erop dat het de EU niet uitmaakt door middel van welk systeem de Europese subsidies die in gedeeld beheer worden verstrekt worden verdeeld. Alle voormelde verdeelsystemen lijken dan ook tot de mogelijkheden te behoren. Zoals in de volgende paragrafen aan de orde komt valt er veel voor te zeggen dat het verdeelsysteem wel moet voldoen aan de eisen die voortvloeien uit de beginselen van transparantie en gelijkheid. Deze beginselen zeggen echter niets over het verdeelsysteem, slechts over de uitvoering daarvan. ${ }^{\mathbf{8 6}}$

De conclusie dat nationale uitvoeringsorganen bij de verstrekking van Europese subsidies in gedeeld beheer geen tenderprocedure zouden moeten hanteren, kan echter niet in alle gevallen worden getrokken. Uit de toelichting op de

Nederlandse besluiten waarin voor de verdeling van ESF-subsidies Comités van Experts worden ingesteld, blijkt namelijk dat de Commissie van mening is dat de selectiemethoden "wie het eerst komt, het eerst maalt" en/of "loting" in het kader van ESF in beginsel niet zijn toegestaan. ${ }^{\mathbf{8}}$ Waarop de Commissie dit standpunt baseert en of dit standpunt ook voor andere Europese subsidies geldt, wordt niet expliciet duidelijk gemaakt, maar is wel begrijpelijk. Alleen in een tenderprocedure is immers gegarandeerd dat de beste projecten een Europese subsidie ontvangen. Hoewel in een "wie het eerst komt, het eerst maalt"-systeem wel op kwaliteit kan worden getoetst, vindt geen onderlinge vergelijking plaats tussen de verschillende projecten. De EU vindt het belangrijk dat alleen de beste projecten worden geselecteerd, hetgeen ook blijkt uit het feit dat voor de verdeling van de Europese subsidies die door de Europese Commissie worden verstrekt het gebruik van een tenderprocedure is voorgeschreven.

Het voormelde Commissiestandpunt ten spijt, vooralsnog bevat de Europese subsidieregelgeving voor de verdeling van Europese subsidies in gedeeld beheer geen verplichting om een tenderprocedure te gebruiken. Om te bewerkstelligen dat nationale uitvoeringsorganen ook bij de verdeling van deze Europese subsidies een tenderprocedure zullen hanteren, zal de EU met Europese regelgeving moeten komen.

\subsection{Europeesrechtelijke eisen aan de verdeling van schaarse}




\section{Europese subsidies die door de Europese Commissie, uitvoerende Europese agentschappen en nationale agentschappen worden verstrekt ((indirect) gecentraliseerde wijze)}

\subsubsection{Algemeen}

De verdeling van Europese subsidies die op (indirect) gecentraliseerde wijze door de Europese Commissie, uitvoerende Europese agentschappen en nationale agentschappen worden verstrekt, wordt ingevolge artikel 109 van het Financieel Reglement beheerst door de beginselen van transparantie en gelijkheid. Deze beginselen zijn onder meer ontwikkeld in het aanbestedingsrecht, waarbij het ook gaat om de verdeling van schaarse rechten, namelijk overheidsopdrachten. ${ }^{\mathbf{8 8}} \mathrm{Bij}$ de aanbestedingsprocedure dient het beginsel van gelijke behandeling te worden geëerbiedigd zodat de inschrijvers gelijke kansen hebben. ${ }^{\mathbf{8 9}}$ Teneinde enerzijds dergelijke gelijke kansen daadwerkelijk te scheppen ${ }^{90}$ en anderzijds de naleving van het gelijkheidsbeginsel te kunnen controleren, moet de gehele aanbestedingsprocedure - van aankondiging tot gunning - 'transparant' zijn. ${ }^{\mathbf{9 1}}$ Doelstelling van deze beginselen is om favoritisme en willekeur aan de kant van de aanbestedende dienst uit te sluiten.

In deze paragraaf wordt per fase de tenderprocedure beschreven zoals deze geldt voor de verdeling van Europese subsidies die door de Europese Commissie, uitvoerende Europese agentschappen en nationale agentschappen worden verstrekt. Uitgangspunt daarbij zijn de voorschriften die zijn neergelegd in het Financieel Reglement en de daarop gebaseerde verordening van de Europese Commissie. Interessant is verder de wijze waarop deze voorschriften worden uitgewerkt in de verordeningen en besluiten die gelden voor de Europese subsidies afzonderlijk. Het voert te ver om in deze bijdrage iedere Europese subsidie die door de Europese Commissie, uitvoerende Europese agentschappen en nationale agentschappen wordt verstrekt te bespreken. Ter illustratie wordt dan ook alleen ingegaan op de subsidieprogramma's Een Leven Lang Leren en Jeugd in Actie. Deze Europese subsidies zijn gekozen als voorbeeldmateriaal nu zij weliswaar door nationale uitvoeringsorganen worden verstrekt, maar waarop toch de subsidietitel van het Financieel Reglement van toepassing is. Dit betekent dat nationale uitvoeringsorganen bij de verdeling van deze Europese subsidies in ieder geval de beginselen van gelijkheid en transparantie moeten toepassen.

\subsubsection{Voorafgaande bekendmaking van de mogelijkheid om een Europese subsidie aan te vragen, de procedure en de voorwaarden om voor een subsidie in aanmerking te komen}

Allereerst dient de Europese oproep tot het indienen van voorstellen door het orgaan dat de Europese subsidie verstrekt te worden gepubliceerd op de internetsite van de Europese instellingen en eventueel op een ander gepaste wijze, zoals in het publicatieblad van de EU.92 Aangegeven is tot welke uiterste datum de subsidieaanvraag kan worden ingediend. Voorts zijn in de oproepen de subsidiabiliteits-, uitsluitings-, 93 selectie-, ${ }^{94}$ geschiktheids- 95 en

toekenningscriteria, ${ }^{\mathbf{9 6}}$ alsmede de bijbehorende bewijsstukken opgenomen en is 
daarin ook de gevolgde procedure te vinden.97 Voor Een Leven Lang Leren en Jeugd in Actie geldt dat in de oproepen tot het indienen van voorstellen - die worden gepubliceerd in het publicatieblad van de EU - wordt verwezen naar de jaarlijks door de Europese Commissie vastgestelde programmagidsen.98 Hierin zijn alle voormelde criteria neergelegd. Ook is aangegeven hoe de verschillende toekenningscriteria moeten worden gewogen. ${ }^{99}$ Op deze wijze wordt gewaarborgd dat alle potentiële aanvragers gelijke kansen hebben.

\subsubsection{Gelijke behandeling van de binnengekomen aanvragen}

Na de ingekomen aanvragen te hebben geadministreerd, ${ }^{\mathbf{1 0 0}}$ dient het nationale agentschap een selectie te maken van de aanvragen die voor een Europese subsidie in aanmerking komen. De beginselen van gelijkheid en transparantie eisen onder meer dat de subsidiabiliteits-, uitsluitings-, selectie-, geschiktheidsen toekenningscriteria tijdens de procedure niet mogen worden gewijzigd. ${ }^{\mathbf{1 0 1}}$ Voorts worden te laat ingediende subsidieaanvragen afgewezen. ${ }^{\mathbf{1 0 2}} \mathrm{Met}$ wijzigingen en aanvullingen van (onvolledige) subsidieaanvragen wordt terughoudend omgegaan. Dit betekent concreet dat het nationaal agentschap spontane wijzigingen of aanvullingen op aanvragen slechts accepteert tot de uiterste indieningstermijn. ${ }^{\mathbf{1 0 3}}$ Wijzigingen of aanvullingen van een essentieel karakter die daarna worden ingediend, worden in ieder geval buiten beschouwing gelaten. ${ }^{\mathbf{1 0 4}}$ Een nationaal agentschap kan de aanvrager wel de gelegenheid geven om binnen een redelijke deadline formele en duidelijke vergissingen te rectificeren, of om nader bewijs te leveren dat aan de formele criteria is voldaan. ${ }^{\mathbf{1 0 5}}$ Een verplichting is dit echter niet. Hoofdregel is dat nadat de aanvraag is ingediend, niets meer kan worden gewijzigd. ${ }^{\mathbf{1 0 6}} \mathrm{De}$ subsidieverstrekker dient gelet op het gelijkheids- en transparantiebeginsel sowieso terughoudend te zijn in contacten met de subsidieaanvragers. In de programmagids Jeugd in Actie is dan ook vermeld dat het nationaal agentschap weliswaar ondersteuning biedt onder meer tijdens de aanvraagprocedure, maar dit niet in strijd mag komen met de eis van een eerlijke en transparante selectieprocedure. ${ }^{107}$ Daartegenover staat dat dezelfde programmagids ook laat zien dat gelijke behandeling van aanvragers niet altijd voldoende is om te waarborgen dat aanvragers daadwerkelijk kansen hebben op een Europese subsidie. Soms kan het nodig zijn om bepaalde categorieën aanvragers - zoals nieuwkomers - meer hulp te geven, omdat deze categorieën anders minder kans zouden hebben op honorering van de aanvraag. ${ }^{\mathbf{1 0 8}}$ Terughoudendheid in contacten met subsidieaanvragers, is derhalve niet altijd regel in de tenderprocedure.

\subsubsection{Evaluatiecomités en experts}

Voor de beoordeling van de subsidieaanvragen in het kader van Europese subsidies die op (indirect) gecentraliseerde wijze worden verstrekt, worden tenzij de Europese Commissie anders heeft bepaald - comités voor de evaluaties ingeschakeld. ${ }^{\mathbf{1 0 9}}$ Evaluatiecomités zijn belast met de evaluatie van de ingediende voorstellen. ${ }^{\mathbf{1 1 0}}$ Besloten kan worden dat het comité door externe deskundigen wordt bijgestaan. ${ }^{\mathbf{1 1 1}}$

Zowel in het kader van Een Leven Lang Leren als Jeugd in Actie is voorzien in 
een dergelijk evaluatiecomité. ${ }^{\mathbf{1 1 2}}$ Voor Een Leven Lang Leren geldt bovendien dat elke subsidieaanvraag die aan de geschiktheids- en uitsluitingscriteria voldoet door doorgaans minimaal twee experts wordt beoordeeld op kwaliteit. ${ }^{\mathbf{1 1 3}}$ Uit het document "Minimum requirements for assessors" blijkt dat daarbij tenminste één van de twee een externe expert moet zijn. ${ }^{\mathbf{1 1 4}}$ Dit zijn experts die niet in dienst zijn bij het nationaal agentschap dat de toekenningsprocedure voor de Europese subsidies organiseert. ${ }^{\mathbf{1 1 5}} \mathrm{Bij}$ de verdeling van Europese subsidies in het kader van Jeugd in Actie worden slechts bij uitzondering externe experts ingeschakeld. ${ }^{\mathbf{1 1 6}}$

Evaluatiecomités bestaan in het kader van Een Leven Lang Leren uit leden van het nationaal agentschap, externe experts en vertegenwoordigers van belanghebbenden.117 Evaluatiecomités die worden ingezet bij de verdeling van Een Leven Lang Leren-subsidies zijn expliciet belast met het houden van toezicht op het gehele selectieproces. ${ }^{\mathbf{1 1 8}}$ De comités houden zich dus niet bezig met een individuele beoordeling of de ingekomen aanvragen voldoen aan uitsluitings-, selectie-, geschiktheids- en toekenningscriteria. ${ }^{\mathbf{1 1 9}}$ De beoordeling of de ingekomen aanvragen voldoen aan deze criteria wordt verricht door het nationaal agentschap en door experts. De evaluatiecomités doen op basis van de beoordeling door het nationaal agentschap en de experts een voorstel, waarin wordt aangegeven welke aanvragen moeten worden gehonoreerd, geweigerd of op een reservelijst moeten worden geplaatst. ${ }^{\mathbf{1 2 0}} \mathrm{Zij}$ dienen in dat kader te garanderen dat alle aanvragers door een eerlijke en transparante toepassing van de procedures gelijk worden behandeld. ${ }^{\mathbf{1 2 1}}$ De procedureregels die van toepassing zijn op de werkwijze van de evaluatiecomités moeten voorts voorzien in een objectieve methode voor de rangschikking van aanvragen die dezelfde kwaliteit hebben. ${ }^{\mathbf{1 2 2}}$

De werkwijze van de experts en de evaluatiecomités is beschreven in de door de Europese Commissie uitgegeven, maar niet-gepubliceerde Gids voor nationale agentschappen. ${ }^{\mathbf{1 2 3}}$ Ook in de Commissieverordening behorend bij het Financieel Reglement is een aantal regels terug te vinden. Zo kan het evaluatiecomité op grond van artikel 178, tweede lid, de aanvrager verzoeken bijkomende inlichtingen te verstrekken of de ingediende bewijsstukken met betrekking tot de aanvraag toe te lichten, met name in het geval van kennelijke schrijffouten. Het nationaal agentschap is verplicht om procedureregels, ${ }^{\mathbf{1 2 4}}$

beoordelingsformulieren en checklisten vast te stellen. Verder moeten de experts en de evaluatiecomités door het nationaal agentschap op de hoogte worden gebracht van het subsidieverstrekkingsproces en over de verschillende acties die gesubsidieerd kunnen worden. In dat kader is voorgeschreven dat het nationaal agentschap trainingen geeft aan experts en leden van het evaluatiecomité. De experts en de evaluatiecomités zijn uiteraard gebonden aan de door de Europese Commissie in de programmagidsen neergelegde criteria en de weging van ieder criterium.

Met het inschakelen van een evaluatiecomité en experts wordt bevorderd dat alle aanvragen onpartijdig, objectief en gelijk worden behandeld. Om te waarborgen dat de experts en het evaluatiecomité daadwerkelijk onafhankelijk zijn, is in de Gids voor nationale agentschappen neergelegd dat zij een formele verklaring moeten tekenen om belangenverstrengeling te voorkomen. Verder mogen 
personen die betrokken zijn geweest bij de beoordeling of aan de geschiktheids-, uitsluitings-, selectie- of toekenningscriteria is voldaan, geen beslissende rol hebben in het evaluatiecomité. Om te waarborgen dat de experts hun beoordeling individueel en onafhankelijk uitvoeren, gebruiken zij een afzonderlijk beoordelingsformulier. De experts bepalen de score van de ingediende subsidieaanvraag. In het Nederlandse contract dat met experts wordt gesloten is onder meer opgenomen dat de expert zich ertoe verbindt de beoordelingen geheel onafhankelijk uit te voeren zonder enige beperkingen of invloeden, ongeacht de aard of het soort en onmiddellijk het nationaal agentschap in te lichten bij enige poging tot beïnvloeding of drukuitoefening. ${ }^{\mathbf{1 2 5}}$ Zij mogen voorts geen subsidie ontvangen in de selectieronde waarin zij in de beoordeling participeren. ${ }^{\mathbf{1 2 6}}$ De Gids voor nationale agentschappen voor Een Leven Lang Leren schrijft voor dat externe experts op een transparante wijze moeten worden geworven, bij voorkeur door middel van een openbare tenderprocedure. ${ }^{\mathbf{1 2 7}}$ Uit de Nederlandse uitvoeringspraktijk blijkt dat de experts voor hun bewezen diensten een vergoeding ontvangen. ${ }^{\mathbf{1 2 8}}$ De Europese subsidieregelgeving inzake Jeugd in Actie en Een Leven Lang Leren vereist niet dat de namen van de externe experts bekend worden gemaakt.

Werknemers van het nationaal agentschap kunnen experts zijn of zitting hebben in een evaluatiecomité. Ook voor hen geldt dat zij geen subsidie kunnen aanvragen in het kader van Een Leven Lang Leren. ${ }^{\mathbf{1 2 9}}$

Zoals gezegd doen de evaluatiecomités op basis van de beoordeling door het nationaal agentschap en de experts een voorstel, waarin wordt aangegeven welke aanvragen moeten worden gehonoreerd, geweigerd of op een reservelijst moeten worden geplaatst. Uiteindelijk neemt het nationaal agentschap de besluiten omtrent de ingediende subsidieaanvragen. Indien een nationaal agentschap van het voorstel van het evaluatiecomité afwijkt, moet in het besluit op de subsidieaanvraag daarvoor een duidelijke rechtvaardiging worden gegeven. ${ }^{\mathbf{1 3 0}}$ Uitgangspunt is derhalve dat het voorstel van het evaluatiecomite wordt overgenomen. Hiervoor bestaat een goede reden: indien sprake is van een onafhankelijk evaluatiecomité en onafhankelijke experts, is het niet zonder meer te verdedigen dat een nationaal uitvoeringsorgaan zou concluderen dat het voorstel van het evaluatiecomité ondeugdelijk is. Het verdient aanbeveling dat nationale agentschappen alleen van het voorstel afwijken indien is komen vast te staan dat het evaluatiecomité zich niet aan de procedures heeft gehouden, dan wel is uitgegaan van onjuiste feiten.

\subsubsection{Controle naleving beginselen van transparantie en gelijkheid}

Omdat controleerbaar moet zijn of de selectieprocedure voldoet aan de beginselen van transparantie en gelijkheid, moeten alle fasen van het subsidieverstrekkingsproces worden gedocumenteerd. Allereerst dient het orgaan dat de Europese subsidie verstrekt een passend register bij te houden waarin alle contacten met de aanvragers gedurende de procedure worden neergelegd. ${ }^{\mathbf{1 3 1}}$ Ten tweede tekenen de leden van het evaluatiecomité aan het einde van de werkzaamheden een proces-verbaal, waarin alle onderzochte voorstellen en de kwaliteit ervan zijn opgenomen en wordt vastgesteld welke 
voorstellen voor een Europese subsidie in aanmerking komen.132 Dit procesverbaal wordt bewaard, zodat het later kan worden geraadpleegd. ${ }^{\mathbf{1 3 3}} \mathrm{Niet}$ duidelijk is of dit proces-verbaal openbaar wordt gemaakt, dan wel ter kennis wordt gebracht van de subsidieaanvragers. Het verdedigingsbeginsel lijkt hiertoe niet te verplichten, nu een beslissing over de kwaliteit van een subsidieaanvraag op zijn hoogst ertoe kan leiden dat de subsidieaanvraag wordt afgewezen. Het verdedigingsbeginsel is slechts van toepassing indien een particulier door een handeling van een nationaal uitvoeringsorgaan in een nadeliger positie komt te verkeren. ${ }^{\mathbf{1 3 4}}$ Bij de afwijzing van een subsidieaanvraag zal daarvan niet snel sprake zijn. ${ }^{\mathbf{1 3 5}}$ In het vervolg van deze paragraaf zal worden onderzocht of het transparantiebeginsel in combinatie met het verdedigingsbeginsel hiertoe wel kan verplichten. ${ }^{\mathbf{3 6}}$

In dat kader is de zaak Fisher interessant. ${ }^{137}$ In deze zaak hadden landbouwers voor het indienen van een aanvraag voor een Europese subsidie voor akkergebouwgewassen informatie nodig over het gebruik van de grond in voorgaande jaren. Het subsidieverstrekkende nationaal uitvoeringsorgaan weigerde echter de benodigde informatie te verstrekken. Doordat de Fishers niet over de juiste gegevens beschikten, bevatte hun subsidieaanvraag diverse fouten, hetgeen een boete tot gevolg had. Omdat de rechten van de verdediging bij een bezwarende handeling moeten worden gewaarborgd, wordt aan de Fishers in het kader van oplegging van de boete de voor de aanvraag benodigde informatie alsnog verstrekt. Buijze en Widdershoven merken terecht op dat dit een onbevredigende uitkomst is. ${ }^{\mathbf{1 3 8}}$ Als het bestuur eerder inzage had verleend, hadden de Fishers een correcte subsidieaanvraag kunnen indienen, was de boete nooit opgelegd en hadden de Fishers zich niet hoeven verdedigen. ${ }^{\mathbf{1 3 9}}$

Uiteindelijk komt de zaak bij het Hof van Justitie terecht. In dat verband is allereerst de conclusie van de advocaat-generaal interessant. De advocaatgeneraal stelt voorop dat de bevoegde instantie verplicht is om al vóór de indiening van de aanvraag er actief aan mee te werken dat de gegevens correct zijn. ${ }^{\mathbf{1 4 0}}$ In sommige gevallen kan dit volgens de advocaat-generaal leiden tot een verplichting om inlichtingen te verschaffen, namelijk wanneer de aanvrager de gegevens absoluut nodig heeft voor de subsidieaanvraag en om sancties te voorkomen, alsmede wanneer rechten van derden - met name rechten die onder de gegevensbescherming vallen - zich daartegen niet verzetten. Dit moet van geval tot geval door een belangenafweging worden geverifieerd. Transparantie van het openbaar bestuur kan alleen in geval van bijzondere rechtvaardigingsgronden worden beperkt, aldus de advocaat-generaal, na een gedetailleerde belangenafweging. De advocaat-generaal formuleert vervolgens de voorwaarden waaraan volgens hem moet zijn voldaan, voordat beschermde gegevens ook zonder uitdrukkelijke goedkeuring van de betrokkene mogen worden meegedeeld. In dat kader komt de advocaat-generaal tot de conclusie dat de belangen van de Fishers prevaleren boven die van degene op wie de beschermde gegevens betrekking hebben. Buijze en Widdershoven leiden hieruit af dat de advocaat-generaal van mening is dat wanneer het Europese recht een bepaald belang erkent - in dit geval de economische en financiële belangen van de subsidieaanvrager die ook naar voren komen in de Europese verordening transparantie is vereist wanneer dat voor het realiseren van dat belang nodig is. ${ }^{\mathbf{1 4 1}}$ Het Hof komt ook tot de conclusie dat de gegevens aan de Fishers hadden moeten worden verstrekt, maar baseert de uitspraak niet expliciet op het 
transparantiebeginsel. ${ }^{\mathbf{1 4 2}}$ Het Hof hanteert een teleologische interpretatie; het doel van de verordening wordt het gemakkelijkst bereikt door de Fishers in een vroeg stadium toegang te verlenen tot de informatie. ${ }^{\mathbf{1 4 3}}$ Volgens het Hof geldt derhalve materieel een transparantieverplichting, namelijk in die mate dat het doel van de Europese regeling wordt bereikt. ${ }^{\mathbf{1 4 4}}$ Buijze en Widdershoven trekken uit het arrest de conclusie dat de burger op grond van het transparantiebeginsel een individueel recht heeft op openbaarheid van stukken, wanneer dat noodzakelijk is voor het realiseren van een door het Europese recht erkend belang. ${ }^{\mathbf{1 4 5}}$ Wel geldt dat volgens het Hof van Justitie daarbij steeds rekening moet worden gehouden met het fundamentele recht op bescherming van persoonsgegevens. ${ }^{\mathbf{1 4 6}}$

Mijn inziens is dit arrest ook relevant voor de vraag of de aanvrager van een Europese subsidie wiens aanvraag is afgewezen, inzage moet krijgen in het proces-verbaal waarin van alle ingediende subsidieaanvragen het kwaliteitsoordeel is opgenomen. De subsidieaanvrager heeft deze informatie nodig om zijn relatieve kwaliteitsoordeel te kunnen bestrijden in het kader van een procedure tegen de afwijzing van zijn subsidieaanvraag. Dit belang wordt in de Europese subsidieregelgeving Jeugd in Actie en Een Leven Lang Leren expliciet erkend, nu uit de toepasselijke regelgeving volgt dat sprake moet zijn van een eerlijke en transparante toepassing van de procedure. ${ }^{\mathbf{1 4 7}}$ Uit het arrest Fisher kan worden afgeleid dat voor de aanvrager van een Europese subsidie wiens aanvraag is afgewezen een individueel recht op openbaarheid van stukken bestaat, zij het dat daarbij rekening moet worden gehouden met het fundamentele recht op bescherming van persoonsgegevens van de overige aanvragers.

De niet-openbaarmaking van voormeld proces-verbaal staat verder op gespannen voet met het beginsel van effectieve rechtsbescherming. Indien een aanvrager onvoldoende toegang heeft tot de op (de totstandkoming van) de rangorde betrekking hebben de stukken, wordt het immers lastig de relatieve afwijzing van de subsidieaanvraag aan te vechten. ${ }^{\mathbf{1 4 8}} \mathrm{Er}$ zijn derhalve genoeg Europeesrechtelijke redenen om aan te nemen dat openbaarmaking van het proces-verbaal waarin de door het evaluatiecomité gemaakte rangorde en de motivering is neergelegd, een vereiste is.

Het voorgaande is slechts anders indien de motivering van het besluit van het nationaal uitvoeringsorgaan zelf de aanvragers waarvan de aanvraag is afgewezen voldoende in staat stelt het afwijzingsbesluit aan te vechten. In dat verband is relevant dat uit het Financieel Reglement volgt dat het orgaan dat de Europese subsidie verstrekt de aanvrager schriftelijk op de hoogte moeten brengen van het gevolg dat aan de door hem ingediende subsidieaanvraag is gegeven. ${ }^{\mathbf{1 4 9}}$ In het besluit tot afwijzing van de Europese subsidie dient het orgaan voorts te motiveren waarom de aanvraag wordt afgewezen in relatie tot de vooraf gepubliceerde selectie- en toekenningscriteria en prioriteiten. ${ }^{\mathbf{1 5 0}}$ Ingevolge artikel 178, vierde lid, van de Commissieverordening behorend bij het Financieel Reglement dient het subsidieverstrekkend orgaan in het besluit te vermelden de namen van de begunstigden, de omschrijving van de acties, de toegekende bedragen en de redenen van deze keuze en de naam van de afgewezen aanvragers en de redenen voor deze keuze. Deze bepaling wijst erop 
dat er één besluit wordt genomen dat aan alle aanvragers wordt toegezonden. De Gids voor nationale agentschappen Een Leven Lang Leren lijkt echter ervan uit te gaan dat afzonderlijke besluiten worden genomen, ${ }^{\mathbf{1 5 1}}$ zodat openbaarmaking van het proces-verbaal noodzakelijk is om te weten om welke redenen andere aanvragen zijn gehonoreerd dan wel afgewezen. Het voorgaande betekent dat van geval tot geval zal moeten worden bezien of openbaarmaking van het procesverbaal noodzakelijk is.

\subsubsection{Tussenconclusie}

Uit de vorige paragrafen blijkt dat aan de verdeling van Europese subsidies die op (indirect) gecentraliseerde wijze worden verstrekt allerlei Europeesrechtelijke eisen worden gesteld. Veel van deze eisen zijn terug te voeren op de beginselen van transparantie en gelijkheid. Zij beogen te bewerkstelligen dat iedere potentiële aanvrager een gelijke kans heeft om een Europese subsidie te verkrijgen. Dat deze beginselen niet alleen betekenis hebben in het aanbestedingsrecht, maar ook van toepassing zijn op de verstrekking van Europese subsidies is niet verwonderlijk. ${ }^{\mathbf{1 5 2}} \mathrm{Er}$ bestaat immers geen principieel verschil tussen de verstrekking van schaarse opdrachten en schaarse Europese subsidies. Het subsidierecht vereconomiseert; in toenemende mate zijn subsidieaanvragers elkaars concurrenten. ${ }^{\mathbf{1 5 3}}$ In de volgende paragraaf wordt bezien of soortgelijke Europeesrechtelijke eisen ook worden gesteld aan de verdeling van Europese subsidies die in gedeeld beheer worden verstrekt.

\subsection{Europeesrechtelijke eisen aan de verdeling van schaarse Europese subsidies die in gedeeld beheer worden verstrekt}

\subsubsection{Algemeen}

Wat betreft de verdeling van Europese subsidies die in gedeeld beheer worden verstrekt, zijn op Europees niveau veel minder regels vastgesteld. Het Financieel Reglement en de daarbij behorende Commissieverordening bevatten überhaupt geen regels over de verdeling van dergelijke Europese subsidies. ${ }^{\mathbf{1 5 4}}$ In de specifieke Europese regelgeving die ziet op de verstrekking van Europese subsidies in gedeeld beheer is wel een aantal regels terug te vinden. Ten eerste is daarin neergelegd dat het nationaal uitvoeringsorgaan de procedures instelt voor de selectie van projecten die voor Europese subsidies in aanmerking komen en dat selectiecriteria worden vastgesteld. ${ }^{\mathbf{1 5 5}}$ Ten tweede is in meer of mindere mate voorgeschreven dat aan de mogelijkheid tot het aanvragen van een Europese subsidie ruime bekendheid moet worden gegeven. ${ }^{\mathbf{1 5 6}}$ De Europese subsidieregelgeving die ziet op de Migratiefondsen bepaalt voorts dat de selectiecriteria (vooraf) bekend moeten worden gemaakt ${ }^{\mathbf{1 5 7}}$, stelt eisen aan de motivering van de beslissing om subsidie toe te kennen ${ }^{\mathbf{1 5} 8}$ en schrijft voor dat de redenen waarom projecten niet worden geselecteerd worden opgetekend. ${ }^{\mathbf{1 5 9}} \mathrm{In}$ het kader van de structuurfondsen ESF en EFRO, het Europees Visserijfonds en het ELFPO is expliciet bepaald dat het nationaal uitvoeringsorgaan aan potentiële begunstigden duidelijke en gedetailleerde informatie verstrekt over ten minste de beschrijving van de procedures voor de behandeling van subsidieaanvragen en van de daarmee gemoeide tijd en de criteria voor de selectie van de te subsidiëren projecten. ${ }^{\mathbf{1 6 0}}$ Voormelde eisen zijn terug te voeren 
op de beginselen van gelijkheid en transparantie. Deze beginselen worden echter niet expliciet van toepassing verklaard op de nationale procedure die nationale uitvoeringsorganen hanteren bij de selectie van de aanvragen voor Europese subsidies.

\subsubsection{Toepasselijkheid van de beginselen van transparantie en gelijkheid op de verstrekking van schaarse Europese subsidies in gedeeld beheer?}

De vraag rijst of het feit dat het gelijkheids- en transparantiebeginsel niet expliciet van toepassing zijn verklaard op de verdeling van Europese subsidies die in gedeeld beheer worden verstrekt, ook betekent dat deze beginselen en de daaruit voortvloeiende eisen - voor zover deze eisen niet in de desbetreffende Europese subsidieregelgeving zijn voorgeschreven - niet door nationale uitvoeringsorganen in acht moeten worden genomen. In deze paragraaf wordt een aantal argumenten besproken waaruit kan worden afgeleid dat voormelde beginselen ook van toepassing zijn indien nationale uitvoeringsorganen Europese subsidies in gedeeld beheer verstrekken.

Indien in de Europese regelgeving geen regels omtrent de verdeling van Europese subsidies zijn voorgeschreven, geldt als hoofdregel dat het nationale recht van toepassing is. De toepassing van het nationale recht wordt echter beperkt door de beginselen van gelijkwaardigheid en doeltreffendheid. Voor zover de verdeling van nationale subsidies niet wordt beheerst door de beginselen van transparantie en gelijkheid, is het gelet op het gelijkwaardigheidsbeginsel niet problematisch dat deze beginselen ook niet worden toegepast bij de verdeling van Europese subsidies. Vereist is echter ook dat de toepassing van het nationale recht niet in strijd komt met het doeltreffendheidsbeginsel. Daartoe moet worden bezien of het niet-toepassen van de beginselen van gelijkheid en transparantie de effectuering van het Europese recht praktisch onmogelijk of uiterst moeilijk maakt. In dat kader zou kunnen worden betoogd dat de niet-inachtneming van de beginselen van gelijkheid en transparantie tot gevolg heeft dat niet controleerbaar is of de subsidieverstrekkende autoriteit zich schuldig heeft gemaakt aan favoritisme en willekeur. Dit heeft tot gevolg dat niet is gewaarborgd dat iedere aanvrager gelijke kansen heeft om de Europese subsidie te verkrijgen en derhalve dat de Europese subsidies bij de beste projecten terecht komen. Strijd met het doeltreffendheidsbeginsel zou dus een eerste argument zijn om de stelling dat de beginselen van gelijkheid en transparantie onverkort van toepassing zijn op Europese subsidies die door nationale uitvoeringsorganen worden verstrekt op te baseren.

Ten tweede zijn de door het Hof van Justitie erkende rechtsbeginselen op het handelen van de lidstaten van toepassing, indien zij binnen de werkingssfeer van het EU-recht handelen. ${ }^{\mathbf{1 6 1}}$ Hiervan is onder meer sprake wanneer nationale uitvoeringsorganen het EU-recht uitvoeren, waaronder de Europese subsidieregelgeving. ${ }^{\mathbf{1 6 2}}$ Dat daarbij gebruik wordt gemaakt van het nationale recht, doet daaraan niet af. De omstandigheid dat geen gemeenschappelijke Europese regels zijn vastgesteld over de toepasselijkheid van het gelijkheids- en transparantiebeginsel en dat ook het nationale recht niet in zodanige regels 
voorziet, heeft dus niet tot gevolg dat het desbetreffende door het Hof van Justitie erkende rechtsbeginsel geheel niet van toepassing is. ${ }^{\mathbf{1 6 3}}$ Dit betekent dat ook indien een nationaal uitvoeringsorgaan krachtens nationaal recht bij de verstrekking van subsidies niet gehouden is de beginselen van transparantie en gelijkheid en de daaruit voortvloeiende vereisten toe te passen, dat orgaan hiertoe op grond van het Europese recht wel verplicht is indien het om Europese subsidies gaat.

In de Europese jurisprudentie is de toepasselijkheid van de beginselen van transparantie en gelijkheid op de verdeling van Europese subsidies waarvoor geen gemeenschappelijke Europese regels bestaan, nog niet expliciet bevestigd. ${ }^{\mathbf{1 6 4}}$ Wel heeft het Gerecht in het arrest IPK International in algemene zin overwogen dat het transparantiebeginsel en het beginsel van gelijke behandeling van toepassing zijn op de procedure voor de toekenning van subsidies ten laste van de gemeenschapsbegroting, ongeacht het feit dat het oude Financieel Reglement dat in die zaak van toepassing was deze beginselen nog niet noemt. ${ }^{\mathbf{1 6 5}}$ Het Gerecht oordeelt zelfs dat bij de selectie van subsidieaanvragen elke inbreuk op de gelijkheid van kansen en op het transparantiebeginsel een onregelmatigheid is, die de toekenningsprocedure aantast. ${ }^{\mathbf{1 6 6}}$ Hieruit volgt uiteraard - en dat volgt ook uit het huidige artikel 109 van het Financieel Reglement - dat de Europese instellingen en organen die Europese subsidies verstrekken aan het transparantiebeginsel zijn gebonden. ${ }^{\mathbf{1 6}} \mathbf{7}$ Gelet op de formulering "subsidies ten laste van de gemeenschapsbegroting" kan de overweging echter ook zo worden begrepen dat alle Europese subsidies zijn onderworpen aan het transparantiebeginsel, ook als zij door nationale uitvoeringsorganen worden verstrekt. Zeker is dit niet, omdat Europese subsidies die in gedeeld beheer worden verstrekt - zoals besproken in paragraaf 2.1 van deze bijdrage - , niet onder de definitie van artikel 108, eerste lid, van het Financieel Reglement vallen. Het staat echter vast dat met de inwerkingtreding van het nieuwe Financieel Reglement over de toepasselijkheid van het transparantiebeginsel op de verstrekking van Europese subsidies door nationale uitvoeringsorganen, ook in gedeeld beheer, geen misverstand meer kan bestaan. Daarin is namelijk neergelegd dat de lidstaten indien zij middelen van de Unie beheren, met inachtneming van het transparantiebeginsel handelen. ${ }^{\mathbf{1 6 8}}$ Inmiddels zijn in oktober 2011 de commissievoorstellen wat betreft de verstrekking van Europese subsidies in gedeeld beheer voor de komende programmaperiode 2014-2020 bekendgemaakt. Ook daarin is expliciet bepaald dat de nationale autoriteit die de Europese subsidies verstrekt voor de selectie van concrete acties passende selectieprocedures en -criteria opstelt en toepast die niet-discriminerend en transparant zijn. ${ }^{\mathbf{1 6 9}}$ Deze voorstellen zijn uiteraard nog niet in werking getreden.

Mocht voormeld arrest van het Gerecht minder ruim moeten worden geïnterpreteerd, dan bestaat op dit moment ook nog een ander argument op grond waarvan het goed voorstelbaar is dat subsidieverstrekking door nationale uitvoeringsorganen moet voldoen aan de beginselen van transparantie en gelijkheid. Dit argument geldt niet alleen voor Europese subsidies die in gedeeld beheer worden verstrekt, maar ook voor subsidies die met nationaal geld worden bekostigd. De tandem van beide beginselen wordt door het Hof van Justitie namelijk steeds vaker ook op procedures toegepast buiten het terrein van de 
aanbesteding. De beginselen van gelijkheid en transparantie zijn niet meer alleen van toepassing indien voor een nationale overheid een aanbestedingsverplichting geldt, maar ook als het gaat om aanbestedingen onder de drempel, de verlening van concessies en schaarse dienstenvergunningen. ${ }^{\mathbf{1 7 0}}$ Ook een nationale autoriteit die een schaarse vergunning verleent, moet een passende mate van openbaarheid garanderen, zodat het recht voor mededinging openstaat en de gunningsprocedure op onpartijdigheid kan worden getoetst. ${ }^{\mathbf{1 7 1}}$

Het Hof van Justitie acht de beginselen van transparantie en gelijkheid van toepassing op de verdeling van steeds meer schaarse publieke rechten. Het transparantiebeginsel heeft zich op Europees niveau derhalve ontwikkeld tot een algemeen rechtsbeginsel. ${ }^{\mathbf{1 7 2}}$ Dit betekent dat het beginsel mogelijkerwijs naar andere gebieden kan worden geëxtrapoleerd dan die van aanbestedingsrecht, concessies en schaarse vergunningen. ${ }^{\mathbf{1 7 3}}$ Het transparantiebeginsel vindt langzaam zijn weg van het aanbestedingsrecht naar andere terreinen van het (Europees) bestuursrecht. 174

In dat kader is belangrijk dat de meeste (Europese) subsidies - zeker in deze tijden van economische crisis - zijn aan te merken als schaarse rechten. ${ }^{\mathbf{1 7 5}} \mathrm{Uit}$ de jurisprudentie van het Hof Justitie over de verdeling van opdrachten, concessies en schaarse vergunningen blijkt echter wel dat de beginselen van gelijkheid en transparantie naar Europees recht pas van toepassing zijn, indien sprake is van een grensoverschrijdend belang. ${ }^{\mathbf{1 7 6}}$ Hiervan is sprake indien een ondernemer die is gevestigd in een andere lidstaat dan die waar de betrokken dienstenconcessie/vergunning wordt verleend, in deze concessie/vergunning geïnteresseerd kan zijn. ${ }^{\mathbf{1 7 7}}$ In dat geval moet het mogelijk zijn voor andere Europese spelers om mee te dingen naar een nationale concessie/vergunning. Uit het arrest SECAP blijkt dat - vertaald naar het subsidierecht - daarbij relevant zou kunnen zijn de geraamde waarde van de te verstrekken subsidies en de plaats van uitvoering. ${ }^{\mathbf{1 7}} \mathbf{8}$ Waarschijnlijk lijkt dat niet te snel mag worden aangenomen dat geen sprake is van een grensoverschrijdend belang. Bovendien rijst bij de verstrekking van schaarse Europese subsidies door nationale uitvoeringsorganen - anders dan bij louter nationale subsidies - de vraag of het criterium dat sprake moet zijn van een grensoverschrijdend belang wel relevant is. De verdeling van Europese subsidies valt immers zonder meer binnen het EU-recht, reeds omdat het gaat om de uitvoering van EU-recht. Dit duidt erop dat de Europese beginselen van gelijkheid en transparantie zonder meer van toepassing zijn. Voor zover het criterium van grensoverschrijdend belang toch betekenis toekomt bij de verdeling van Europese subsidies door nationale uitvoeringsorganen, is het voorts niet uitgesloten dat ook buitenlandse instellingen belangstelling kunnen hebben voor de uitvoering van deze projecten met Europese subsidies. In dat kader is relevant dat uit de Europese subsidieregelgeving blijkt dat eindontvangers van Europese subsidies die onder het aanbestedingsrecht vallen - hierbij zal het doorgaans om overheden gaan de aanbestedingsregels, inclusief de beginselen van gelijkheid en transparantie, moeten naleven wanneer zij de projecten - gefinancierd met Europese subsidies - laten uitvoeren door derden. Daarbij wordt eveneens als criterium gehanteerd dat ondernemers uit andere lidstaten geïnteresseerd kunnen zijn in de uitvoering van het desbetreffende project. ${ }^{\mathbf{1 7 9}}$ De Commissie houdt in dat kader rekening met de aard van de opdrachten, de betrokken belangen en de geografische locatie waar de opdrachten moeten worden uitgevoerd en is van 
mening dat indien het gaat om bedragen dicht bij de drempels het grensoverschrijdend belang is gelegen in het bedrag zelf. ${ }^{\mathbf{1 8 0}}$ In veel gevallen worden echter helemaal geen derden ingeschakeld, maar worden (delen van) projecten door eindontvangers van de Europese subsidies zelf uitgevoerd. Het gaat daarbij met name om subsidieontvangers die niet tot de overheid behoren. Het ligt niet voor de hand dat de beginselen van gelijkheid en transparantie niet in beeld komen in gevallen waarin het nationaal uitvoeringsorgaan de Europese subsidies verstrekt aan eindontvangers die de projecten zelf uitvoeren, terwijl dat anders komt te liggen zodra de eindontvanger voor de uitvoering van het project derden inschakelt.

Gelet op het vorenstaande, valt er veel voor te zeggen dat het transparantiebeginsel als waarborg voor de verwezenlijking van het gelijkheidsbeginsel, ook van toepassing is op de verdeling van schaarse Europese subsidies die door nationale uitvoeringsorganen in gedeeld beheer worden verstrekt. Dit betekent bijvoorbeeld dat nationale uitvoeringsorganen de criteria om voor een Europese subsidie in aanmerking te komen niet meer mogen wijzigen nadat de aanvragen zijn ingediend, dat wijzigingen en aanvullingen van de aanvragen niet zonder meer mogen worden geaccepteerd en dat, voor zover experts en commissies worden ingeschakeld, zij de beoordeling van de aanvragen onafhankelijk moeten uitvoeren. Voorts moet ook controleerbaar zijn of de selectieprocedure aan de beginselen van gelijkheid en transparantie voldoet. Feit is wel dat hieromtrent nog geen Europese jurisprudentie bestaat. Deze paragraaf laat echter zien dat het Hof van Justitie weinig overwegingen nodig zal hebben om de beginselen van gelijkheid en transparantie ook van toepassing te verklaren op de verstrekking van andere Europese en nationale subsidies. ${ }^{\mathbf{1 8 1}}$

\subsection{Rechtsbescherming tegen een schending van de beginselen van transparantie en gelijkheid bij de verdeling van schaarse Europese subsidies}

Ervan uitgaande dat de Europese beginselen van gelijkheid en transparantie van toepassing zijn op de verdeling van alle Europese subsidies - ongeacht of zij op (indirect) gecentraliseerde wijze dan wel in gedeeld beheer worden verstrekt - , rijst de vraag in hoeverre de Europese subsidieregelgeving eisen stelt aan de rechtsbescherming tegen schendingen van deze beginselen bij de verdeling van schaarse Europese subsidies. Het zal daarbij doorgaans gaan om een aanvrager wiens aanvraag om een Europese subsidie is afgewezen en die van mening is dat deze beginselen bij de verdeling van de Europese subsidie niet in acht zijn genomen. In de Europese subsidieregelgeving die ziet op de verstrekking van Europese subsidies door de Europese Commissie, Europese uitvoerende agentschappen en nationale agentschappen, bestaan hieromtrent geen specifieke regels. Hetzelfde geldt voor de Europese subsidieregelgeving die ziet op de verstrekking van Europese subsidies in gedeeld beheer. Anders dan in de Europese aanbestedingsrichtlijnen, is in de Europese subsidieregelgeving niet voorzien in een doeltreffende en snelle beroepsmogelijkheid tegen de door de subsidieverstrekker genomen besluiten nadat is bekendgemaakt welke projecten zullen worden gesubsidieerd. ${ }^{\mathbf{1 8 2}}$ Het Europese aanbestedingsrecht vereist anders dan de Europese subsidieregelgeving - voorts dat de rechter de 
mogelijkheid moet hebben om een voorlopige maatregel te treffen, om onwettige besluiten nietig te (doen) verklaren en om schadevergoeding toe te kennen. ${ }^{\mathbf{8 3}}$ Uit de jurisprudentie van het Hof van Justitie blijkt dat tegen het besluit waarbij een overheidsopdracht wordt gegund beroep tot nietigverklaring moet kunnen worden ingesteld, voordat de aanbestedende dienst en de uitverkoren particulier een overeenkomst mogen sluiten. ${ }^{\mathbf{1 8 4}}$ Deze mogelijkheid moet bestaan los van de mogelijkheid om na het sluiten van de overeenkomst schadevergoeding te verkrijgen. ${ }^{\mathbf{1 8 5}}$ Inmiddels is deze jurisprudentie in de richtlijn nr. 665/1989 gecodificeerd. ${ }^{\mathbf{1 8 6}}$ De codificatie houdt in dat voor het sluiten van de overeenkomst een standstill periode van 10 dagen (bij verzending per fax of email) of 15 dagen (bij andere wijzen van versturing) geldt. ${ }^{\mathbf{1 8} 7}$ Zolang de rechter niet heeft beslist op het beroep tegen het gunningsbesluit dan wel het verzoek om een voorlopige maatregel te nemen mag de overeenkomst niet worden gesloten. ${ }^{\mathbf{1 8 8}}$ Buijze en Widdershoven leiden uit het voorgaande terecht af dat het Europese aanbestedingsrecht de voorkeur heeft voor 'remedies' die de onrechtmatige verdeling van overheidsopdrachten redresseren boven een vervangende schadevergoeding. ${ }^{\mathbf{1 8 9}}$

De Europese subsidieregelgeving voorziet niet in een dergelijke standstillperiode. Ook is niet duidelijk of - indien de Europese of nationale rechter ${ }^{\mathbf{1 9 0}}$ oordeelt dat de subsidietoekenning in strijd is met de beginselen van gelijkheid en transparantie - de Europese subsidie alsnog moet worden verstrekt, of dat de vergelijkende toets zal moeten worden overgedaan, dan wel louter een schadevergoeding volstaat. ${ }^{\mathbf{1 9 1}}$ Indien zowel het besluit tot weigering van de subsidie als het besluit tot subsidietoekenning door de nationale rechter wordt vernietigd, zal in elk geval opnieuw op de aanvragen moeten worden beslist. Het lijkt echter lastig om als (Europese) rechter te oordelen dat de vergelijkende toets moet worden overgedaan, indien jaren nadat de Europese subsidies zijn verdeeld tot de conclusie wordt gekomen dat de verdeelprocedure destijds onrechtmatig was. In dat geval ligt een schadevergoeding meer voor de hand. Er bestaan (nog) geen aanwijzingen in de Europese jurisprudentie dat de eisen aan de rechtsbescherming die in het Europese aanbestedingsrecht worden gesteld, reeds voortvloeien uit het beginsel van effectieve rechtsbescherming. Uit het arrest Unibet kan immers worden geconcludeerd dat een procedure ter verkrijgen van schadevergoeding in geval van schending van het EU-recht juist wel een effectief rechtsmiddel kan zijn. ${ }^{192}$

Het is twijfelachtig of een dergelijke schadevergoedingsprocedure uiteindelijk zal leiden tot schadevergoeding. Uit de Europese jurisprudentie ten aanzien van Europese subsidies die door de Europese Commissie worden verstrekt, blijkt dat op grond van de enkele vernietiging van het besluit tot weigering van de subsidie nog geen aanspraak bestaat op een schadevergoeding. ${ }^{193}$ Schadevergoeding is pas aan de orde indien vast komt te staan dat zonder schending van de beginselen van gelijkheid en transparantie positief op de aanvraag zou zijn beslist. ${ }^{\mathbf{1 9 4}}$ Dit betekent dat, los van de vraag of uiteindelijk een Europese subsidie moet worden verstrekt, ter beoordeling van de schadevergoeding de aanvraag opnieuw moet worden beoordeeld.

Om te waarborgen dat de beginselen van gelijkheid en transparantie daadwerkelijk bescherming bieden bij de verdeling van schaarse Europese 
subsidies, zullen in de Europese subsidieregelgeving specifiekere regels moeten worden neergelegd, inzake de rechtsbescherming tegen toekenningsbesluiten die met deze beginselen in strijd zijn. Voor zover rechtsbescherming bij de nationale rechter openstaat, kan daarbij gedacht worden aan minimumeisen.

\section{Conclusie}

In deze bijdrage is bezien welke Europeesrechtelijke eisen worden gesteld aan de verdeling van schaarse Europese subsidies. Gebleken is dat op Europees niveau met name eisen worden gesteld aan de verdeling van Europese subsidies die op (indirect) gecentraliseerde wijze worden verstrekt. Het gaat daarbij om subsidies die door de Europese Commissie, door Europese uitvoerende agentschappen en door nationale agentschappen worden verstrekt. De verdeling dient plaats te vinden door middel van een tenderprocedure en aan deze procedure worden eisen gesteld die zijn terug te voeren op de in de subsidietitel van het Financieel Reglement expliciet van toepassing verklaarde beginselen van gelijkheid en transparantie. Deze beginselen beogen te bewerkstelligen dat iedere potentiële aanvrager een gelijke kans heeft om een Europese subsidie te verkrijgen.

Voor de overige Europese subsidies die door nationale uitvoeringsorganen in gedeeld beheer worden verstrekt, ligt een en ander wat minder duidelijk. Zo is op Europees niveau niet expliciet voorgeschreven welke systematiek moet worden gehanteerd bij de verdeling van Europese subsidies. Verder bestaan wel wat Europese regels over de procedure tot subsidieverstrekking die zijn terug te voeren tot de beginselen van gelijkheid en transparantie, maar deze beginselen zijn niet expliciet van toepassing verklaard. In paragraaf 3.4.2 is echter een aantal argumenten naar voren gebracht op grond waarvan moet worden geoordeeld dat voormelde beginselen wel degelijk door nationale uitvoeringsorganen die Europese subsidies in gedeeld beheer verstrekken in acht moeten worden genomen. Geconcludeerd is dat de beginselen van transparantie en gelijkheid in ieder geval met ingang van de komende periode 2014-2020 onverkort van toepassing zijn op alle Europese subsidies die door nationale uitvoeringsorganen worden verstrekt.

De toepasselijkheid van de beginselen van transparantie en gelijkheid betekent bijvoorbeeld dat nationale uitvoeringsorganen de criteria om voor een Europese subsidie in aanmerking te komen niet zonder meer mogen wijzigen nadat de aanvragen zijn ingediend, dat wijzigingen en aanvullingen van de ingediende aanvragen niet zonder meer mogen worden geaccepteerd en dat, voor zover experts en commissies worden ingeschakeld, zij de beoordeling van de aanvragen onafhankelijk moeten uitvoeren. Voorts moet controleerbaar zijn of de selectieprocedure aan de beginselen van gelijkheid en transparantie voldoet.

Ten aanzien van de rechtsbescherming tegen een schending van de beginselen van transparantie en gelijkheid bij de verdeling van schaarse Europese subsidies is ten slotte geconcludeerd dat - anders dan in het aanbestedingsrecht - op Europees niveau niet is voorzien in snelle en doeltreffende procedures waarin een dergelijke schending kan worden aangekaart. Om te waarborgen dat de beginselen van gelijkheid en transparantie daadwerkelijk bescherming bieden bij de verdeling van schaarse Europese subsidies, zullen in de Europese 
subsidieregelgeving omtrent de rechtsbescherming specifiekere regels moeten worden neergelegd. Dit neemt niet weg dat op grond van deze bijdrage moet worden geconcludeerd dat de betekenis van de beginselen van gelijkheid en transparantie voor de verdeling van Europese subsidies steeds groter wordt. Dit is een goede zaak.

Alleen dan kan worden gewaarborgd dat schaarse Europese subsidies eerlijk worden verdeeld. Voor subsidieverstrekking in (Europese) achterkamertjes mag geen ruimte zijn!

\section{Noten}

1 Het betreft het Europees Sociaal Fonds (ESF) en het Europees Fonds voor Regionale Ontwikkeling (EFRO).

2 Zie Besluit nr. 1982/2006, Pb. 2006 L 412/1.

3 Een uitzondering bestaat voor enkele Europese subsidieregelingen die uit het Europees Landbouwgarantiefonds worden gefinancierd. Het gaat om de exportrestituties en de bedrijfstoeslag. Voor deze regelingen geldt dat een ieder die aan de subsidievoorwaarden voldoet en zich aan de verplichtingen houdt, in aanmerking komt voor een Europese subsidie. Deze Europese subsidies zijn derhalve niet als schaars aan te merken.

4 De Nederlandse praktijk wijst uit dat hiervan in de meeste gevallen sprake is.

5 De Verordening nr. 1605/2002 van de Raad van 25 juni 2002 houdende het Financieel Reglement van toepassing op de algemene begroting van de Europese Gemeenschappen, Pb. 2002, L 248/1.

6 Dit volgt reeds uit het in artikel 108, eerste lid, van het Financieel Reglement neergelegde woordje "rechtstreeks". In het tweede lid zijn de Europese subsidies die in gedeeld beheer worden verstrekt, dat wil zeggen Europese subsidies die eerst in de begroting van de lidstaat vloeien, bovendien expliciet van het Europees subsidiebegrip uitgezonderd.

7 Zie artikel 1, aanhef en onder 1, van de Verordening nr. 1698/2005 (ELFPO).

8 Zie de Verordening nr. 1782/2003 (ELGF).

9 Zie artikel 14, eerste lid, van de Beschikking nr. 573/2006 (EVF).

10 Zie de Verordening nr. 1038/2006 (structuurfondsen).

11 Zie omtrent het Europese staatssteunrecht bijvoorbeeld Alan Dashwood, Michael Dougan, Barry Rodger, Eleanor Spaventa \& Derrick Wyatt (red.), European Union Law, Oxford And Portland, Oregon: Hart Publishing 2011, p. 847 e.v.; Kelyn Bacon, European Community law of state aid, Oxford: Oxford University Press 2009; L. Hancher, T. Ottervanger \& P.J. Slot, EC State Aids, London: Sweet \& Maxwell 2006; P.C. Adriaanse, Handhaving van EG-recht in 
situaties van onrechtmatige staatssteun, (diss. Amsterdam VU), 2006.

12 Er bestaat slechts één al wat ouder arrest van het Hof van Justitie waarin deze vraag aan de orde is gekomen, namelijk HvJEG 13 oktober 1982, 213/81, 214/81, 215/81 (Norddeutsches Vieh- und Fleischkontor Herbert Will e.a.), Jur. 1982 , p. 3583. In dit arrest moest worden beoordeeld in hoeverre een aandeel in een Europees tariefcontingent was aan te merken als staatssteun, hetgeen tot gevolg heeft dat bepaalde heffingen niet aan de EU behoeven te worden afgedragen. In r.o. 22 en 23 van dit arrest overweegt het Hof van Justitie dat het aan de orde zijnde financiële voordeel niet als staatssteun kan worden aangemerkt, omdat het voordeel niet met staatsmiddelen, maar met Europese middelen wordt bekostigd. Het is de vraag of deze jurisprudentie nog steeds van betekenis is, in het licht van de thans geldende Europese staatssteun- en subsidieregelgeving.

13 Bij uitvoerende Europese agentschappen gaat het om rechtspersonen naar Europees recht waaraan, voor rekening en onder verantwoordelijkheid van de Commissie, de uitvoering van een Europees programma of project geheel of gedeeltelijk kan worden gedelegeerd, overeenkomstig de Verordening nr. 58/2003. Zie artikel 55 van het Financieel Reglement. Zie ook de Verordening nr. 58/2003 van de Raad van 19 december 2002 tot vaststelling van het statuut van de uitvoerende agentschappen waaraan bepaalde taken voor het beheer van communautaire programma's worden gedelegeerd, $P b .2003, \mathrm{~L} \mathrm{11/1.} \mathrm{Zie} \mathrm{omtrent}$ de uitvoerende Europese agentschappen bijvoorbeeld Paul Craig, 'The constitutionalisation of Community administration', ELRev. 2003, p. 840-864, Wolfgang Schenk, Strukturen und Rechtsfragen der gemeinschaftlichten Leistungsverwaltung, Tübingen: Mohr Siebeck 2006, p. 183 e.v..

14 Zie artikel 53 van het Financieel Reglement waarin is neergelegd dat de begroting door de Commissie kan worden uitgevoerd a) op gecentraliseerde wijze, b) onder gedeeld of gedecentraliseerd beheer en c) in gezamenlijk beheer met internationale organisaties.

15 Zie het Besluit nr. 1982/2006 van het Europees Parlement en de Raad van 18 december 2006 betreffende het zevende kaderprogramma van de Europese Gemeenschap voor activiteiten op het gebied van onderzoek, technologische ontwikkeling en demonstratie (2007-2013), $P b .2006$ L 412/1. De procedure van subsidieverstrekking is te vinden in de Verordening nr. 1906/2006 van het Europees Parlement en de Raad van 18 december 2006 tot vaststelling van de regels voor de deelname van ondernemingen, onderzoekscentra en universiteiten aan acties op grond van het zevende kaderprogramma en voor de verspreiding van onderzoeksresultaten (2007-2013), Pb. 2006 L 391/1.

16 Zie de Verordening nr. 614/2007 van het Europees Parlement en de Raad van 23 mei 2007 betreffende het financieringsinstrument voor het Milieu (LIFE+), Pb. 2007, L 149/1.

17 Zie de Verordening nr. 1692/2006 van het Europees Parlement en de Raad van 24 oktober 2006 tot instelling van het tweede Marco Polo-programma voor de toekenning van communautaire financiële bijstand om de milieuprestaties 
van het vrachtvervoerssysteem te verbeteren (Marco Polo II), Pb. 2006 L 328/1.

18 Zie Besluit nr. 1672/2006 van het Europees Parlement en de Raad van 24 oktober 2006 tot vaststelling van een communautair programma voor werkgelegenheid en maatschappelijke solidariteit - Progress, $P b$. 2006 L 315/1.

19 Dit is geschied bij het Commissiebesluit van 26 april 2007 om bevoegdheden over te dragen aan het Uitvoerend Agentschap voor onderwijs, audiovisuele middelen en cultuur (EACEA), met als doel taken uit te voeren die samenhangen met de implementatie van communautaire programma's op het gebied van onderwijs, audiovisuele middelen en cultuur, met inbegrip van met name de implementatie van subsidietoewijzingen zoals vastgelegd in de begroting van de Gemeenschap onder nr. C(2007) 1842, overeenkomstig de wijzigingen van 26 mei 2008. Het agentschap is opgericht bij Besluit van de Commissie van 14 januari 2005 tot oprichting van het Uitvoerend Agentschap Onderwijs, audiovisuele media en cultuur, voor het beheer van de communautaire maatregelen op het gebied van onderwijs, audiovisuele media en cultuur overeenkomstig Verordening nr. 58/2003 van de Raad, Pb. 2005 L 24/35.

20 Dat uitvoerende Europese agentschappen een subsidieverhouding aangaan met eindontvangers van Europese subsidies, leidde in de uitvoeringspraktijk tot de vraag in hoeverre rechtsbescherming openstaat bij de Europese rechter. In artikel 22 van de Verordening nr. 58/2003 is geregeld dat tegen handelingen van een uitvoerend agentschap administratief beroep openstaat bij de Europese Commissie. Als de Europese Commissie het beroep afwijst, staat vervolgens overeenkomstig artikel 263 VWEU beroepen open bij het Gerecht (zie artikel 22, vijfde lid, van de Verordening nr. 58/2003).

21 Zie artikel 108 van het Financieel Reglement en verder.

22 Zie de Verordening nr. 2342/2002 van de Commissie van 23 december 2002 tot vaststelling van uitvoeringsvoorschriften van Verordening nr. 1605/2002 van de Raad van 25 juni 2002 houdende het Financieel Reglement van toepassing op de algemene begroting van de Europese Gemeenschappen, Pb. 2002, L 357/1.

23 Zie artikel 108 bis van het Financieel Reglement.

24 Zie artikel 109 e.v. van het Financieel Reglement.

25 Zie artikel 114 e.v. van het Financieel Reglement.

26 Zie artikel 117 e.v. van het Financieel Reglement.

27 Zie artikel 108, eerste lid, tweede lid, van het Financieel Reglement jo. artikel 164 van de Commissieverordening nr. 2342/2002.

28 Zie het Tweede verslag van het Comité van onafhankelijke deskundigen over de hervorming van de Commissie, Analyse van huidige praktijken en voorstellen voor het aanpakken van wanbeheer, onregelmatigheden en fraude Deel I (10 september 1999), p. 70 en ook artikel 53bis van het voorstel voor een nieuw 
Financieel Reglement. In voormeld verslag wordt van gezamenlijk beheer gesproken, maar dit is slechts een vertaalkwestie; in het Engels gaat het om "shared management". Met de term gezamenlijk beheer wordt dus hetzelfde bedoeld als gedeeld beheer. Craig stelt "shared management" gelijk aan "shared administration". Zie Paul Craig, 'Shared administration, disbursement of community funds and the regulatory state', In: Hofmann \& A. Turk (eds.), Legal Challenges in EU Administrative Law: Towards an Integrated Administration, Cheltenham: Edward Elgar 2009, p. 34-62, p. 34. Ik maak een onderscheid tussen beide begrippen. "Shared management" ziet op de door de lidstaten en de EU gezamenlijke uitvoering van de begroting, terwijl "shared administration" ook op andere vormen van samenwerking ziet.

29 Zie artikel 53 ter, eerste lid, jo. deel II, titels I en II, van het huidige Financieel Reglement.

3o Zie 6.3. onder a van de Commission Staff Working Document on the Review of the Financial Regulation. Dit document is te vinden onder http://www.europa.eu/comparl/cont/site/topics/regulation/5deco5_en.htm.

31 Zie de Verordening nr. 1083/2006 van de Raad van 11 juli 2006 houdende algemene bepalingen inzake het Europees Fonds voor Regionale Ontwikkeling, het Europees Sociaal Fonds en het Cohesiefonds, Pb. 2006, L 210/25.

32 Zie de Verordening nr. 1198/2006 van de Raad van 27 juli 2006 inzake het Europees Visserijfonds, $P b$. 2006, L 223/1.

33 Zie bijvoorbeeld de Verordening nr. 73/2009 van de Raad van 19 januari 2009 tot vaststelling van gemeenschappelijke voorschriften voor regelingen inzake rechtstreekse steunverlening aan landbouwers in het kader van het gemeenschappelijk landbouwbeleid en tot vaststelling van bepaalde steunregelingen voor landbouwers, $P b$. 2009, L 30/16.

34 Zie de Verordening nr. 1698/2005 van de Raad van 20 september 2005 inzake steun voor plattelandsontwikkeling uit het Europees Landbouwfonds voor Plattelandsontwikkeling (ELFPO), Pb. 2005, L 277/1.

35 Zie de Beschikking nr. 573/2007 van het Europees Parlement en de Raad van 23 mei 2007 tot instelling van het Europees Vluchtelingenfonds voor de periode 2008-2013 als onderdeel van het algemeen programma "Solidariteit en beheer van de migratiestromen”, $P b .2007, \mathrm{~L} 144 / 1$.

36 Zie de Beschikking nr. 575/2007 van het Europees Parlement en de Raad van 23 mei 2007 tot oprichting van het Europees Terugkeerfonds voor de periode 2008-2013 als onderdeel van het algemeen programma "Solidariteit en beheer van de migratiestromen”, $\mathrm{Pb} .2007$, L 144/45.

37 Zie de Beschikking van de Raad van 25 juni 2007 tot oprichting van het Europees Fonds voor de integratie van onderdanen van derde landen voor de periode 2007-2013 als onderdeel van het algemeen programma "Solidariteit en beheer van de migratiestromen", $P b .2007, \mathrm{~L}$ 168/18. 
38 Zie de Beschikking nr. 573/2007 van het Europees Parlement en de Raad van 23 mei 2007 tot instelling van het Buitengrenzenfonds voor de periode 20072013 als onderdeel van het algemene programma "Solidariteit en beheer van de migratiestromen”, $\mathrm{Pb} .2007$, L 144/22.

39 Zie de Verordening nr. 1927/2006 van het Europees Parlement en de Raad van 20 december 2006 tot oprichting van een Europees fonds voor aanpassing aan de globalisering, $P b .2006, \mathrm{~L}$ 406/1.

40 Zie het Tweede verslag van het Comité van onafhankelijke deskundigen over de hervorming van de Commissie, Analyse van huidige praktijken en voorstellen voor het aanpakken van wanbeheer, onregelmatigheden en fraude Deel I (10 september 1999), p. 70. Zie ook het voorstel voor een Verordening (EG, EGKS, Euratom) van de Raad houdende het Financieel Reglement van toepassing op de algemene begroting van de Europese Gemeenschappen, 17 oktober 2000, COM (2000) 462 definitief. Zie voorts Paul Craig, EU Administrative Law, New York: Oxford University Press 2006, p. 55.

41 Zie bijvoorbeeld artikel 70, eerste lid, van de Verordening nr. 1083/2006 (Structuurfondsen).

42 Voor de volledigheid zij opgemerkt dat de spelregels in veel gevallen ook zijn neergelegd in Europese soft law. Het gaat daarbij bijvoorbeeld om werkdocumenten en interpretatieve mededelingen waarin is neergelegd hoe bepaalde artikelen uit Europese verordeningen moeten worden uitgelegd. Europese soft law is strikt genomen niet juridisch bindend, maar kan in de praktijk wel juridische effecten hebben. Op het begrip Europese soft law wordt in dit verband niet verder ingegaan. Ik verwijs naar B. Kaya, 'Soft law exiles Hard law: Europese 'soft law' in het nationale bestuursrecht, regelgeving in EUperspectief', in: R.J.N. Schlössels, A.J. Bok, S.D.P. Kole \& A.G.A. Nijmeijer, In de regel. Over kenmerken, structuur en samenhang van geschreven en ongeschreven regels in het bestuursrecht, Kluwer: Deventer 2012, p. 125-143 en J. Luijendijk \& L.A.J. Senden, 'De gelaagde doorwerking van Europese administratieve soft law in de nationale rechtsorde', $S E W$ 2011, p. 312-352.

43 Dit geldt niet voor de Europese subsidies die vanuit het ELGF worden verstrekt.

44 De Structuurfondsen en het Europees Visserijfonds.

\section{Het ELFPO.}

46 De Migratiefondsen.

47 Zie bijvoorbeeld artikel 70, eerste lid, van de Verordening nr. 1975/2006 (ELFPO) en artikel 53, zesde lid, van de Verordening nr. 1083/2006 (Structuurfondsen).

48 De Europese Commissie verstrekt wel voordat de eerste betalingsaanvragen worden ingediend voorschotten aan de lidstaten. Zie bijvoorbeeld artikel 82 van 
de Verordening nr. 1083/2006 (Structuurfondsen). Verder kan de Europese Commissie besluiten betalingen uit te stellen of te schorsen. Zie artikel 91 en 92 van de Verordening nr. 1083/2006 (Structuurfondsen).

49 In artikel 89, eerste lid, van de Verordening nr. 1083/2006 (Structuurfondsen) is deze datum bepaald op 31 maart 2017.

50 Zie hieromtrent ook Hanns Peter Nehl, Europäisches Verwaltungsverfahren und Gemeinschafsverfassung. Eine Studie gemeinschafsrechtlicher Verfahrensgrundsätze unter besonderer Berücksichtigung "mehrstufiger" Verwaltungsverfahren, Berlin: Duncker \& Humblot 2002, p. 75 e.v.. Hij spreekt in dat verband van een "Mehrstufige Verwaltungsverfahren".

$\mathbf{5 1}$ Zie omtrent het begrip procedurele autonomie bijvoorbeeld J.H. Jans, S. Prechal \& R.J.G.M. Widdershoven, Inleiding tot het Europees Bestuursrecht, Nijmegen: Ars Aequi Libri, 2011, p. 36 e.v..

52 Zie omtrent de beginselen van gelijkwaardigheid en effectiviteit Jans e.a. 2011, p. 38 e.v..

53 Zie hieromtrent de Mededeling van de Commissie aan de Raad en het Europees Parlement, beheer van de communautaire programma's door netwerken van nationale agentschappen, COM (2001) 648 (def.). Zie voorts Craig 2003 en Schenk 2006, p. 207 e.v.

54 Het verdient opmerking dat artikel 108, tweede lid, aanhef en onder f, van het Financieel Reglement niet erg duidelijk is. Uit de Europese regels die op de indirect gecentraliseerde subsidies als Een Leven Lang Leren en Jeugd in Actie van toepassing zijn, blijkt echter dat artikel 108 e.v. van het Financieel Reglement van toepassing is. Daarmee moet ook sprake zijn van een subsidie in de zin van artikel 108, eerste lid, van het Financieel Reglement.

55 Zie het Besluit 1720/2006 van het Europees Parlement en de Raad van 15 november 2006 tot vaststelling van een actieprogramma op het gebied van Een Leven Lang Leren, $\mathrm{Pb}$. 2006, L 327/45 en het Besluit nr. 1719/2006 van het Europees Parlement en de Raad van 15 november 2006 tot vaststelling van het programma "Jeugd in actie" voor de periode 2007-2013, Pb. 2006, L 327/30.

56 Zie het Besluit van de Commissie van 20 april 2009 tot oprichting van het Uitvoerend Agentschap Onderwijs, audiovisuele media en cultuur voor het beheer van de communautaire maatregelen op het gebied van onderwijs, audiovisuele media en cultuur, overeenkomstig de Verordening nr. 58/2003 van de Raad, $P b$. 2009, L 101/26.

57 Zie artikel 6, tweede lid, onder b, onder i, van het Besluit 1720/2006 (Een Leven Lang Leren); zie artikel 8, zesde lid, onder b, onder i, van het Besluit 1719/2006 (Jeugd in Actie).

58 Zie artikel 6, tweede lid, onder b, onder i, van het Besluit 1720/2006 (Een Leven Lang Leren); zie artikel 8, zesde lid, onder b, onder i, van het Besluit 
1719/2006 (Jeugd in Actie).

59 De Nederlandse organisatie voor internationale samenwerking in het hoger onderwijs.

6o CINOP Expertisecentrum is een door het ministerie van OCW erkend landelijk expertisecentrum voor het middelbaar beroepsonderwijs in Nederland.

61 www.nji.nl en www.youthinaction.nl.

62 Zie artikel 4, eerste lid, en bijlage 2 bij het Besluit van de Commissie van 26 april 2007, C(2007) 1807 def (Een Leven Lang Leren) en artikel 4, eerste lid, en bijlage 2 bij Besluit van 30 april 2007, C(2007) 2828 def (Jeugd in Actie).

63 Zie de artikelen 4 en 5 van het Besluit van de Commissie van 26 april 2007, C(2007) 1807 def (Een Leven Lang Leren).

64 Zie artikel 4, eerste lid, en bijlage 2 bij het Besluit van de Commissie van 26 april 2007, C(2007) 1807 def (Een Leven Lang Leren) en artikel 4, eerste lid, en bijlage 2 bij het Besluit van de Commissie van 30 april 2007, C(2007) 2828 def (Jeugd in Actie).

65 Zie bijvoorbeeld het programma Een Leven Lang Leren Gids 2012, deel I, II a en II b: http://ec.europa.eu/education/llp/doc848_en.htm.

66 Zie bijvoorbeeld artikel VII van de standaard Grant Agreement for a Erasmus Intensive Programme under the Lifelong Learning Programme, versie 2010, die door de Europese Commissie ter beschikking is gesteld.

67 Schenk 2006, p. 214.

68 Zie het Voorstel voor een verordening van het Europees Parlement en de Raad tot vaststelling van de financiële regels van toepassing op de jaarlijkse begroting van de Unie van 22 december 2010, COM (2010) 815 def.

69 Dit volgt uit paragraaf 5.2.1 van het Voorstel voor een verordening van het Europees Parlement en de Raad houdende het Financieel Reglement van toepassing op de algemene begroting van de EU van 28 mei 2010, COM (2010) 260 def. Dit betreft een andere versie dan het voorstel van 22 december 2010.

70 Zie het voorgestelde artikel 115, jo. artikel 53 van het Financieel Reglement.

$\mathbf{7 1}$ Dit volgt uit het voorgestelde artikel 108, jo. artikel 53, eerste lid, onder a, van het Financieel Reglement.

72 Zie het voorgestelde artikel 53, eerste lid, onder b, van het Financieel Reglement.

73 Zie het voorgestelde artikel 115, tweede lid, onder e, van het Financieel Reglement. 
74 Zo is in artikel 10, tweede lid, van de Europese subsidieverordening Life+ bepaald dat de financiële toewijzing voor de uitvoering van deze regeling voor de periode 2007 tot en met 31 december 2013, 2.143.409.000 euro bedraagt.

75 Zie paragraaf 3.2 van de overeenkomst tussen de Europese Commissie en het Nationaal Agentschap Een Leven Lang Leren 2011 die ziet op het jaar 2011 (niet gepubliceerd).

76 Zie bijvoorbeeld artikel 53, eerste lid, van de Verordening nr. 1083/2006 (Structuurfondsen).

$77 \mathrm{~Pb}$. 2006, C 139/1. Het interinstitutioneel akkoord met betrekking tot de programmaperiode 2000-2006 dateert van 6 mei 1999 ( $P b .1999, \mathrm{C}$ 172/1).

$\mathbf{7 8}$ Zie omtrent de mogelijke verdeelsystemen C.J. Wolswinkel, 'Verdelingsprocedures: een zoektocht naar een zinvol onderscheid', in: F.J. van Ommeren, W. den Ouden \& C.J. Wolswinkel, Schaarse publieke rechten, Den Haag: Boom Juridische Uitgevers, 2011, p. 177-201.

79 Artikel 115 en 116 van het Financieel Reglement.

80 Zie de artikelen 115 en 116 van het Financieel Reglement.

81 Zie bijvoorbeeld M.J. Jacobs \& W. den Ouden, 'Eerlijk zullen wij alles delen..., Ontwikkelingen in de jurisprudentie over de verdeling van de subsidiepot', JBPlus 2011, p 35-58, p. 39 en F.J. van Ommeren, Schaarse vergunningen. De verdeling van schaarse vergunningen als onderdeel van het algemeen bestuursrecht, Deventer: Kluwer 2004, p. 12.

82 Zie artikel 5, tweede lid, onder c, van de Commissieverordening nr. 1828/2006 (Structuurfondsen); bijlage VI bij de Commissieverordening 1974/2006 (ELFPO); artikel 27, eerste lid, onder d, van de beschikking EVF (migratiefondsen).

83 Zie artikel 9, derde lid, van de Commissiebeschikking van 19 december 2007 tot vaststelling van regels voor de uitvoering van Beschikking nr. 573/2007/EG van het Europees Parlement en de Raad tot instelling van het Europees Vluchtelingenfonds voor de periode 2008-2013 als onderdeel van het algemeen programma „Solidariteit en beheer van de migratiestromen” wat betreft de beheers- en controlesystemen van de lidstaten, de regels voor administratief en financieel beheer en de subsidiabiliteit van de uitgaven voor door het Fonds medegefinancierde projecten, $P b .2008 \mathrm{~L}$ 7/1.

84 HvJEG 4 juni 2009, C-241/o7 (JK Otsa Talu), Jur. 2009, p. I-4323, r.o. 38.

85 HvJEG 4 juni 2009, C-241/o7 (JK Otsa Talu), Jur. 2009, p. I-4323, r.o. 54.

86 Ook een 'wie het eerst komt, het eerst maalt'-systeem kan voldoen aan het transparantiebeginsel. Zie F.J. van Ommeren, 'Schaarse publieke rechten: en verplichting tot het creëren van mededingingsruimte?’, In: F.J. van Ommeren, 
W. den Ouden \& C.J. Wolswinkel, Schaarse publieke rechten, Den Haag: Boom Juridische Uitgevers, 2011, p. 235-265, p. 261-262.

87 Zie bijvoorbeeld de toelichting op de Regeling van de Staatssecretaris van Sociale Zaken en Werkgelegenheid van 23 september 2009 tot instelling van een Comité van Experts subsidieregeling ESF 2007-2013/Actie E, Stcrt. 2009/14711, p. 3 .

$\mathbf{8 8}$ Zie voor een mooie vergelijking tussen de verdeling van overheidsopdrachten en de verdeling van schaarse publiekrechten C.E.C. Jansen, 'De gereguleerde aanbesteding en de verdeling van schaarse publieke rechten: een vergelijking', in: F.J. van Ommeren, W. den Ouden \& C.J. Wolswinkel, Schaarse publieke rechten, Den Haag: Boom Juridische Uitgevers, 2011, p. 293-322. Zie omtrent het transparantiebeginsel als Unierechtelijk rechtsbeginsel bijvoorbeeld Jans e.a. 2011, p. 192-199; A.W.G.J. Buijze, 'Waarom het transparantiebeginsel maar niet transparant wil worden', NtER 2011, p. 240-248 en S. Prechal, 'De emancipatie van het algemene transparantiebeginsel', $S E W$ 2008, p. 316- 322.

89 GEU 19 maart 2010, T-50/o5 (Evropaïki Dynamiki/Commissie), Jur. 2010, p. I-01071, r.o. 55; HvJEG 29 april 2004, C-496/99 P (Succhi di frutta), Jur. 2004, p. I-03801, r.o. 108; HvJEG 4 december 2003, C-384/o7 (Wienstrom), Jur. 2003, p. I-14527, r.o. 47; HvJEG 25 april 1996, C-87/94 (Waalse bussen), Jur. 1996, p. I-2043, r.o. 54. Zie ook Widdershoven/Verhoeven e.a., Derde evaluatie van de Algemene wet bestuursrecht, De Europese agenda van de $A w b$, Den Haag: Boom Juridische uitgevers, 2007, p. 86.

90 HvJEG 12 december 2002, C-470/99 (Universale Bau), Jur. 2002, p. I11617, r.o. 93; HvJEG 25 april 1996, C-87/94 (Waalse bussen), Jur. 1996, p. I2043, r.o. 54 .

91 Zie bijvoorbeeld HvJEG 13 september 2007, C-260/o4 (Commissie/Italië), Jur. 2007, p. I-7083, r.o. 24; HvJEG 29 april 2004, C-496/99 P (Succhi di frutta), Jur. 2004, p. I-03801, r.o. 109; HvJEG 12 december 2002, C-470/99 (Universale Bau), Jur. 2002, p. I-11617, r.o. 91; HvJEG 18 oktober 2001, C19/oo (SIAC), Jur. 2001, p. I-7725, r.o. 41. HvJEG 7 december 2000, C-324/98 (Telaustria), Jur. 2000, p. I-10745, r.o. 62.

92 Zie artikel 110, eerste lid, van het Financieel Reglement en artikel 167 van de Commissieverordening behorend bij het Financieel Reglement. Zie ook de Gids voor de nationale agentschappen Een Leven Lang Leren, paragraaf 3.2.

93 De uitsluitingscriteria zien op situaties waarin de subsidieaanvrager zich bevindt en op grond waarvan hij niet in aanmerking kan komen voor een Europese subsidie. Zie ook artikel 114 van het Financieel Reglement.

$94 \mathrm{Bij}$ selectiecriteria gaat het om de evaluatie in hoeverre de organisatie/het partnerschap die/dat de aanvraag indient over de financiële en operationele capaciteit beschikt om de voorgestelde activiteit uit te voeren. Zie artikel 115, eerste lid, van het Financieel Reglement. Zie ook de Programmagids Een Leven Lang Leren 2011, p. 29-30. 
95 De geschiktheidscriteria behelzen de formele vereisten waaraan een subsidieaanvraag moet voldoen. Zie ook artikel 175bis, tweede lid, van de Commissieverordening bij het Financieel Reglement.

96 De toekenningscriteria zien op de kwaliteit van de subsidieaanvraag; op basis van deze criteria worden de aanvragen met elkaar vergeleken. Zie de Programmagids Een Leven Lang Leren 2011, p. 30-31.

97 Dit volgt uit artikel 167, eerste lid, van de Commissieverordening bij het Financieel Reglement.

98 Zie bijvoorbeeld de oproep tot het indienen van voorstellen 2012, Programma Een Leven Lang Leren, $P b$. 2011, C 233/15, p. 16.

99 Zie bijvoorbeeld de Programmagids Een Leven Lang Leren 2011, p. 31. Overigens geldt in het aanbestedingsrecht dat de onderlinge weging van de criteria niet vooraf openbaar behoeven te worden gemaakt. Het is ook toegestaan dat de weging van de criteria na ontvangst van de offertes wordt vastgesteld. . Zie HvJEU 18 november 2010, C-226/o9 (Commissie/Ierland), n.n.g., r.o. 43 en 44, NJ 2011, 87.

100 Zie de Gids voor de nationale agentschappen Een Leven Lang Leren, 3.5.1.

101 Zie artikel 116, eerste lid, van de het Financieel Reglement en de Gids voor de nationale agentschappen Een Leven Lang Leren, 3.6.1.2 en 3.6.2.2.1.

102 Zie de Programmagids Een Leven Lang Leren 2011, p. 26.

103 Gids voor Nationale Agentschappen Een Leven Lang Leren, 3.5, punt 5 .

104 Gids voor Nationale Agentschappen Een Leven Lang Leren, 3.5, punt 6.

105 Zie de Programmagids Jeugd in Actie 2011, p. 117 en Gids voor Nationale Agentschappen Een Leven Lang Leren, 3.6.2.1.3.

106 Programmagids Jeugd in Actie 2011, p. 117.

107 Programmagids Jeugd in Actie 2011, p. 25.

108 Programmagids Jeugd in Actie 2011, p. 25.

109 Dit volgt uit artikel 178 van de Commissieverordening behorend bij het Financieel Reglement.

110 Zie artikel 178, eerste lid, van de Commissieverordening behorend bij het Financieel Reglement.

111 Zie artikel 178, eerste lid, van de Commissieverordening behorend bij het Financieel Reglement. 
112 Zie de Programmagids Een Leven Lang Leren 2011, p. 25. Zie ook de Gids voor de nationale agentschappen Een Leven Lang Leren, 3.6.2.3;

113 Programmagids Een Leven Lang Leren 2011, p. 25. Uit de Gids voor Nationale Agentschappen Een Leven Lang Leren blijkt dat het om een minimumaantal experts gaat. In het algemeen wordt geadviseerd zo veel mogelijk externe beoordelaars in te schakelen. Zie 3.6.3.2, 3 .

114 "Minimum requirements for assessors", versie december 2010.

115 Programmagids Een Leven Lang Leren 2011, p. 25.

116 Gids voor de nationale agentschappen Jeugd in Actie, p. 21-22.

117 Zie de Programmagids Een Leven Lang Leren 2011, p. 25.

118 Zie de Programmagids Een Leven Lang Leren 2011, p. 25.

119 Dit is ingevolge artikel 178, eerste lid, van de Commissieverordening behorend bij het Financieel Reglement wel de algemene omschrijving van de taak van het evaluatiecomité.

120 Zie de Gids voor de nationale agentschappen Een Leven Lang Leren, 3.6.2.3.6.

121 Zie de Programmagids Een Leven Lang Leren 2011, p. 25.

122 Zie de Gids voor de nationale agentschappen Een Leven Lang Leren, 3.6.2.3.6.

123 In artikel 4, derde lid, van het Commissiebesluit van 26 april 2007 betreffende de verantwoordelijkheden van respectievelijk de lidstaten, de Commissie en de nationale agentschappen bij de uitvoering van het programma op het gebied van een leven lang leren (2007-2013) is bepaald dat het nationaal agentschap zijn taken uitvoert conform de "Gids voor nationale agentschappen", die de minimumvoorwaarden bevat voor interne controlestandaarden die van toepassing zijn op nationale agentschappen en hun beheer van de projecten die worden gefinancierd. Zie omtrent de werkwijze van experts en evaluatiecomités met name, punt 3.6.2 en 3.6.1 van de Gids voor nationale agentschappen.

124 Gids voor Nationale Agentschappen Een Leven Lang Leren, 3.6.2.3.4. De procedureregels moeten zijn vastgesteld en medegedeeld aan het evaluatiecomité voordat met de beoordeling wordt begonnen. De procedureregels bevatten minstens een gedetailleerde werkwijze van het evaluatiecomité en de formele regels voor het nemen van beslissingen. Op grond van artikel 178, lid 1bis, wordt de procedure ook in het de oproepen tot het indienen van voorstellen bekendgemaakt.

125 Zie het contract voor onafhankelijke deskundigen ter beoordeling van projectvoorstellen ingediend in het kader van het Europese actieprogramma Een 
Leven Lang Leren, Leonardo da Vinci.

126 Gids voor Nationale Agentschappen Een Leven Lang Leren, 3.6.3.1.

127 Gids voor Nationale Agentschappen Een Leven Lang Leren, 3.6.3.3.

128 Uit de Oproep tot kandidaatstelling van het Nederlandse Nationaal Agentschap Een Leven Lang Leren blijkt dat daarvoor een vergoeding wordt toegekend variërend van 75 tot 125 euro. Ook het EACEA schakelt experts in bij de beoordeling van de aanvragen die op Europees niveau in het kader van Een Leven Lang Leren worden ingediend. Ook zij ontvangen een vergoeding. Zie de oproep tot het indienen van blijken van belangstelling EACEA/o7 met het oog op de samenstelling van een lijst van deskundigen die ermee worden belast het Uitvoerend Agentschap Onderwijs, audiovisuele media en cultuur bij te staan in het kader van het beheer van de communautaire programma's op het gebied van onderwijs, audiovisuele media, cultuur, jeugd en burgerschap, $\mathrm{Pb}$. 2008, C $67 / 51$.

129 Zie de Gids voor de nationale agentschappen Een Leven Lang Leren, 3.6.3.1.

130 Zie artikel 178, vierde lid, van de Commissieverordening behorend bij het Financieel Reglement en de Gids voor de nationale agentschappen Een Leven Lang Leren, 3.6.2.4.4.

131 Zie artikel 178, tweede lid, van de Commissieverordening behorend bij het Financieel Reglement.

132 Artikel 178, derde lid, van de Commissieverordening van het Financieel Reglement.

133 Artikel 178, derde lid, van de Commissieverordening van het Financieel Reglement.

134 Zie HvJEG 24 oktober 1996, C-32/95 (Lisretal), Jur. 1996, p. I-5373 waarin de vermindering van een toegekende Europese subsidie wel als een bezwarende handeling wordt aangemerkt.

135 Van Rijn van Alkemade noemt de situatie waarin de afwijzing de beëindiging van een langdurige subsidierelatie markeert. Zie J.M.J. van Rijn van Alkemade, 'Rechtsbescherming bij de verdeling van schaarse subsidies: motivering en (processuele) openbaarheid', In: F.J. van Ommeren, W. den Ouden \& C.J. Wolswinkel, Schaarse publieke rechten, Den Haag: Boom Juridische Uitgevers 2011, p. 379-409, p. 403.

136 Zie A.W.G.J. Buijze \& R.J.G.M. Widdershoven, 'De Awb en EU-recht: het transparantiebeginsel', in: T. Barkhuysen, W. den Ouden \& J.E.M. Polak, Bestuursrecht harmoniseren: 15jaar Awb, Den Haag 2010, p. 589-607, p. 604.

137 HvJEG 14 september 2000, C-369/98 (Fisher), Jur. 2000, p. I-6751. 
138 Buijze \& Widdershoven 2010, p. 604.

139 Buijze \& Widdershoven 2010, p. 604.

140 Zie de conclusie van de advocaat-generaal Alber bij HvJEG 14 september 2000, C-369/98 (Fisher), punt 43.

141 Buijze \& Widdershoven 2010, p. 604.

142 HvJEG 14 september 2000, C-369/98 (Fisher), Jur. 200o, p. I-6751, r.o. 36 e.v..

143 HvJEG 14 september 2000, C-369/98 (Fisher), Jur. 2000, p. I-6751, r.o. 27.

144 Buijze \& Widdershoven 2010, 604.

145 Buijze \& Widdershoven 2010, p. 604-605.

146 HvJEG 14 september 2000, C-369/98 (Fisher), Jur. 2000, p. I-6751, r.o. 32 e.v. Het recht op bescherming van persoonsgegevens is thans neergelegd in artikel 8 van het Handvest EU en de privacyrichtlijn (richtlijn 95/46 van het Europees Parlement en de Raad van 24 oktober 1995 betreffende de bescherming van natuurlijke personen in verband met de verwerking van persoonsgegevens en betreffende het vrije verkeer van die gegevens, $P b$. 1995, L 281/31)

147 Programmagids Een Leven Lang Leren 2011, p. 25.

148 Zie hieromtrent Van Rijn van Alkemade 2011, p. 407.

149 Zie artikel 116, derde lid, van het Financieel Reglement en de Gids voor de nationale agentschappen Een Leven Lang Leren, 3.6.2.4. Ingevolge artikel 179 van de Commissieverordening behorend bij het Financieel Reglement dient dit binnen 15 kalenderdagen te geschieden nadat het toekenningsbesluit aan de begunstigden is toegezonden.

150 Zie artikel 116, derde lid, van het Financieel Reglement en de Gids voor de nationale agentschappen Een Leven Lang Leren, 3.6.4.3.

$\mathbf{1 5 1}$ Zie artikel 3.6.2.4, lid 2.

152 Overigens worden de beginselen in het aanbestedingsrecht en het Europees subsidierecht niet helemaal hetzelfde uitgelegd. In de Europese subsidieregelgeving kan ik bijvoorbeeld niet terugvinden dat de selectiecriteria zodanig moeten zijn geformuleerd dat iedere redelijk geïnformeerde en zorgvuldige subsidieaanvrager ze op dezelfde manier zal interpreteren. Het spreekt mijns inziens voor zich dat de selectiecriteria die worden gehanteerd voor de verdeling van Europese subsidies, ook aan deze eis moeten voldoen.

153 Zie hieromtrent de annotatie van W. den Ouden bij ABRvS 20 oktober 2010, 
$A B$ 2011, 232, m.nt. W. den Ouden; Widdershoven/Verhoeven e.a. 2007, p. 205 e.v..

$\mathbf{1 5 4}$ Zie artikel 53ter van het Financieel Reglement.

$\mathbf{1 5 5}$ Zie wat betreft de in te stellen procedures bijvoorbeeld artikel 27, eerste lid, aanhef en onder d, van de Beschikking nr. 573/2007 (EVF) en artikel 5, tweede lid, onder b, van de Commissieverordening 1828/2006 (structuurfondsen). Zie wat betreft de selectiecriteria artikel 75, eerste lid, onder a, van de Verordening nr. 1698/2005 (ELFPO); artikel 59, aanhef en onder a, van de Verordening nr. 1198/2006 (Europees Visserijfonds) en artikel 60, aanhef en onder a, van de Verordening nr. 1083/2006 (structuurfondsen).

$\mathbf{1 5 6}$ Voor de Migratiefondsen is expliciet bepaald dat oproepen tot het indienen van voorstellen moeten worden bekendgemaakt die onder meer de doelstellingen, de selectiecriteria en de relevante bewijsstukken moeten bevatten, zie bijvoorbeeld artikel 9, eerste lid, van de Commissiebeschikking EVF. Voor de overige Europese subsidieregelingen geldt dat op zijn hoogst is voorgeschreven dat de lidstaten publiciteit geven aan de mogelijkheid om voor Europese subsidies in aanmerking te komen. Zie artikel 5, eerste lid, van de Commissieverordening nr. 1828/2006 (Structuurfondsen), artikel 29, eerste lid, van de Commissieverordening nr. 498/2007 (EVF), bijlage VI, onder 1.1, van de Commissieverordening nr. 1974/2006 (ELFPO) en artikel 8, eerste lid, van de Commissieverordening 501/2008 (voorlichtings- en afzetbevorderingsacties).

$\mathbf{1 5 7}$ Zie artikel 9, eerste lid, onder b, van de Commissiebeschikking EVF.

158 Selectiebesluiten moeten worden toegelicht: zie artikel 9, zesde lid, van de Commissiebeschikking EVF.

159 Zie artikel 9, derde lid, van de Commissiebeschikking EVF. Niet duidelijk is of dit ook betekent dat deze redenen richting de subsidieaanvrager moeten worden gecommuniceerd.

160 Zie artikel 5, tweede lid, aanhef en onder b en c, van de Commissie verordening nr. 1828/2006 (structuurfondsen); artikel 29, tweede lid, aanhef en onder b en c, van de Commissieverordening nr. 498/2007 (Europees Visserijfonds) en bijlage VI bij de Commissieverordening nr. 1974/2006 (ELFPO).

161 Vergelijk Jans e.a. 2011, p. 123. Zie ook HvJEG 18 december 2008, C349/o7 (Sopropé), Jur. 2008, p. I-10369, AB 2009, 29, m.nt. R.G.J.M. Widdershoven.

162 Zie HvJEG 25 november 1986, gevoegde zaken 201 en 202/85 (Klensch), Jur. 1986, p. 3477, r.o. 10. Zie ook HvJEG 4 juni 2009, C-241/o7 (Otsa Talu/Pollumajanduse), Jur. 2009, p. I-04323, r.o. 46; HvJEG 14 september 2006, C-181/o4-C-183/o4 (Elmeka), Jur. 2006, p. I-8167, r.o. 31; HvJEG 26 april 2005, C-376/o2 (Goed Wonen), Jur. 2005, p. I-3445, r.o. 32; HvJEG 3 december 1998, C-381/97 (Belgocodex), Jur. I-8153, r.o. 26; HvJEG 13 juli 1989, 
5/88 (Wachauf), Jur. 1989, p. 2609, r.o. 19. Zie ook Jans e.a. 2011, p. 124; Sacha Prechal, 'Competence Creep and General Principles of Law', REALaw 2009, p. 5-22, p. 8 en Takis Tridimas, The General Principles of EU Law, Oxford: Oxford University Press 2006, p. 36 e.v.

163 Uit HvJEG 18 december 2008, C-349/o7 (Sopropé), Jur. 2008, p. I-10369, $A B$ 2009, 29, m.nt. R.G.J.M. Widdershoven, r.o. 38, volgt wel dat het Hof bij de tenuitvoerlegging van dat beginsel de procedurele autonomie van de lidstaat voorop stelt, indien over een bepaald aspect van het beginsel geen gemeenschappelijke Europese regels bestaan. De tenuitvoerlegging van het beginsel wordt in dat geval bepaald door het nationale recht, mits is voldaan aan de beginselen van gelijkwaardigheid en doeltreffendheid.

164 Hiertoe had het Hof van Justitie wel de gelegenheid in het arrest JK Otsa Talu (HvJEG 4 juni 2009, C-241/o7, Jur. 2009, p. I-4323). Het Hof overweegt als besproken - enkel dat de lidstaten zich moeten inspannen om hun financiële middelen aldus te beheren dat zij aan iedere in aanmerking komende aanvrager in de zin van die verordening steun voor plattelandsontwikkeling kunnen verlenen.

165 GEU 15 april 2011, T-297/O5 (IPK International), n.n.g., AB 2011, 285, m.nt. A. Drahmann, $S E W$ 2012, 49, m.nt. J.C.A. van Dam en J.E. van den Brink, r.o. 123. Het oude Financieel Reglement dateert van 21 december 1977, Pb. 1977, L 356/1. Het Financieel Reglement was destijds niet neergelegd in een verordening.

166 GEU 15 april 2011, T-297/O5 (IPK International), n.n.g., AB 2011, 285, m.nt. A. Drahmann, $S E W$ 2012, 49, m.nt. J.C.A. van Dam en J.E. van den Brink, r.o. 125 .

167 Zie hieromtrent ook Van Ommeren, Den Ouden \& Wolswinkel 2011, p. 1864 .

168 Zie artikel 56 van het Voorstel voor een verordening van het Europees Parlement en de Raad houdende het Financieel Reglement van toepassing op de algemene begroting van de EU van 22 december 2010, COM (2010) 815 def

169 Zie artikel 114, derde lid, onder a, aanhef en onder i, van het voorstel voor een Verordening van het Europees Parlement en de Raad houdende gemeenschappelijke bepalingen inzake het EFRO, het ESF, het Cohesiefonds, het ELFPO en het Europees Fonds voor maritieme zaken en visserij, die onder het gemeenschappelijk strategisch kader vallen, en algemene bepalingen inzake het EFRO, het ESF en het Cohesiefonds. De desbetreffende bepaling ziet alleen op het EFRO, ESF en het Cohesiefonds.

170 HvJEU 9 september 2010, C-64/o8 (Ernst Engelmann), n.n.g.; HvJEU 13 april 2010, C-91/o8 (Wall), Jur. 2010, p. I-02815; HvJEG 13 september 2007, C-26o/o4 (Commissie/Italië), Jur. 2007, p. I-7083; HvJEG 6 april 2006, C410/o4 (ANAV), Jur. 2006, p. I-3303; HvJEG 21 juli 2005, C-231/o3 (Coname), Jur. 2005, p. I-7287; HvJEG 7 december 2000, C-324/98 (Telaustria), Jur. 
2000, p. I-10745, r.o. 60-62; HvJEG 18 november 1999, C-275/98 (Unitron), Jur. 1999, p. I-8291, r.o. 31. Zie ook Buijze \& Widdershoven 2010, p. 593.

171 Dit volgt uit het zogenoemde Betfair-arrest (HvJEU 3 juni 2010, C-203/o8, $A B$ 2011, 17, m.nt. A. Buijze, JB 2010/171, m.nt. C.J. Wolswinkel, NJ 2010/490, m.nt. M.R. Mok onder $N J$ 2010/491, $S E W$ 2011/33, m.nt. A.J.C. de Moor-van Vugt).

172 Vergelijk Jans e.a. 2011, p. 192; Buijze 2011, p. 241 e.v.;

Widdershoven/Verhoeven e.a. 2007, p. 90. Het Hof van Justitie heeft het beginsel als zodanig voor het eerst erkend in HvJEG 13 september 2007, C260/o4 (Commissie/Italië), Jur. 2007, p. I-7083. Er bestaat nog wel discussie over de vraag in hoeverre sprake is van een zelfstandig algemeen rechtsbeginsel. Zie Jans e.a. 2011, p. 194; Buijze 2011, p. 242.

173 Widdershoven/Verhoeven e.a. 2007, p. 90. Drahmann is van mening dat ook los van het Europese recht het transparantiebeginsel van toepassing zou moeten zijn op de verdeling van Europese subsidies. Zie A. Drahmann, 'Is het strikte onderscheid tussen subsidie- en opdrachtverlening nog houdbaar?', Gst. 2011, p. 620-631 en A. Drahmann, 'Kan het subsidierecht transparanter?', Gst. 2011, p. 672-684.

174 Zie de noot van Den Ouden onder ABRvS 15 december 2010, $A B$ 2011, 87, punt 3, laatste alinea. Zie ook Buijze 2011.

175 Vergelijk Annemarie Drahmann, 'Streven naar een transparante (her)verdeling van schaarse publieke rechten', in: Van Ommeren, Den Ouden \& Wolswinkel (red.), Schaarse publieke rechten, Den Haag: Boom Juridische Uitgevers 2011, p. 267-292, p. 285-286.

176 Zie bijvoorbeeld Frank van Ommeren, Willemien den Ouden \& Johan Wolswinkel, 'Schaarse publieke rechten. Wat Bard, Betfair en BNR met elkaar gemeen hebben', $N J B$ 2011, p. 1858-1866, p. 1863-1864. In andere gevallen is sprake van een zogenoemde “interne situatie”. Zie ook E.H. Pijnacker Hordijk, G.W. van der Bend \& J.F. van Nouhuys, Aanbestedingsrecht, Handboek van het Europees en het Nederlandse aanbestedingsrecht, Den Haag: Sdu Uitgevers bv 2009, p. 16 e.v.

177 Zie bijvoorbeeld HvJEU 9 september 2010, C-64/o8 (Engelmann), n.n.g., r.o. 50 en 53 en HvJEU 3 juni 2010, C-203/o8 (Betfair), Jur. 2010, p. I-4695, $A B$ 2011, 17, m.nt. Buijze, $J B$ 2010/171, m.nt. Wolswinkel, r.o. 47. In eerdere jurisprudentie sprak het Hof van een "duidelijk grensoverschrijdend belang”. Het is nog niet uitgekristalliseerd in hoeverre het criterium "mogelijkerwijs in andere lidstaten geïnteresseerde gevestigde ondernemingen" een nuancering betekent. Zie H.M. Stergiou, 'Het Hof van Justitie: Engelbewaarder van het transparantiebeginsel', NtER 2011, p. 77-87, p. 85.

178 HvJEG 15 mei 2008, C-147/o6 en C-148/o6 (SECAP en Santorso), Jur. 2008, p. I-3565. 
179 Dit blijkt bijvoorbeeld uit het standpunt van de Commissie in GEU 14 april 2011, T-70/o9 (Nederland/Commissie), n.n.g., $A B$ 2011, 368, m.nt. J.E. van den Brink en C. de Kruif.

180 Zie eveneens het standpunt van de Commissie in GEU 14 april 2011, T70/o9 (Nederland/Commissie), n.n.g., r.o. 33-34, $A B$ 2011, 368, m.nt. J.E. van den Brink en C. de Kruif.

181 In GEU 15 april 2011, T-297/O5 (IPK International), n.n.g., AB 2011, 285, m.nt. A. Drahmann, $S E W$ 2012, 49, m.nt. J.C.A. van Dam en J.E. van den Brink, r.o. $122-126$, wordt de koppeling met het aanbestedingsrecht en de jurisprudentie daaromtrent al gelegd.

182 Zie artikel 1, eerste lid, van de Richtlijn nr. 665/1989.

183 Zie artikel 1, tweede lid, van de Richtlijn nr. 665/1989. Zie hieromtrent ook Buijze \& Widdershoven 2011, p. 419.

184 HvJEG 28 oktober 1999, C-81/98 (Alcatel), Jur. 1999, p. I-7671, r.o. 43.

185 HvJEG 28 oktober 1999, C-81/98 (Alcatel), Jur. 1999, p. I-7671, r.o. 43.

186 Zie hieromtrent ook Buijze \& Widdershoven 2011, p. 419.

$\mathbf{1 8 7}$ Zie artikel 2bis, tweede lid, van de Richtlijn 665/1989.

188 Zie artikel 2, derde lid, van de Richtlijn 665/1989.

189 Buijze \& Widdershoven 2011, p. 419.

190 Voor zover de Europese subsidie is verstrekt door de Commissie en Europese uitvoerende agentschappen zal het om de Europese rechter gaan. Voor zover het Europese subsidies betreft die door nationale agentschappen dan wel in gedeeld beheer worden verstrekt, is de nationale rechter bevoegd om kennis te nemen van beroepen tegen de subsidietoekenning.

191 Zie voor de problematiek omtrent de bestuursrechtelijke beslechting van geschillen over de verdeling van schaarse rechten omdat sprake is van een vergelijkende toets B.J. Schueler, 'Bestuursrechtelijke beslechting van geschillen over de verdeling van schaarse publieke rechten', In: F.J. van Ommeren, W. den Ouden \& C.J. Wolswinkel (red.), Schaarse publieke rechten, Den Haag: Boom Juridische Uitgevers 2011, p. 363-378.

192 HvJEG 13 maart 2007, C-432/o5 (Unibet), Jur. 2007, p. I-2271, r.o. 44, $A B$ 2007, 301, m.nt. De Waele en Schutgens.

193 Zie GvEA 18 mei 1995, T-478/93 (Wafer Zoo), Jur. 1995, p. II-1497. In deze zaak kwam het Gerecht tot de conclusie dat in strijd met het rechtszekerheidsbeginsel de selectiecriteria niet waren gepubliceerd. Voor het rechtszekerheidsbeginsel zou ook het transparantiebeginsel kunnen worden 
ingevuld.

194 In het arrest Wafer Zoo overweegt het Gerecht dat vast moet staan dat de aanvrager zonder toepassing van een criterium dat niet aan hem is

bekendgemaakt voor de Europese subsidie in aanmerking zou zijn gekomen, omdat hij voldeed aan de andere criteria. In dit arrest was echter geen sprake van een vergelijkende toets.

(c) Boom Juridische uitgevers 